\title{
WestVirginiaUniversity
}

THE RESEARCH REPOSITORY @ WVU

Graduate Theses, Dissertations, and Problem Reports

2014

\section{Long Exposure: environmental racism and activism in Institute, West Virginia}

Allyssa Sobey

Follow this and additional works at: https://researchrepository.wvu.edu/etd

\section{Recommended Citation}

Sobey, Allyssa, "Long Exposure: environmental racism and activism in Institute, West Virginia" (2014). Graduate Theses, Dissertations, and Problem Reports. 6686.

https://researchrepository.wvu.edu/etd/6686

This Thesis is protected by copyright and/or related rights. It has been brought to you by the The Research Repository @ WVU with permission from the rights-holder(s). You are free to use this Thesis in any way that is permitted by the copyright and related rights legislation that applies to your use. For other uses you must obtain permission from the rights-holder(s) directly, unless additional rights are indicated by a Creative Commons license in the record and/ or on the work itself. This Thesis has been accepted for inclusion in WVU Graduate Theses, Dissertations, and Problem Reports collection by an authorized administrator of The Research Repository @ WVU. For more information, please contact researchrepository@mail.wvu.edu. 
Long Exposure: environmental racism and activism in Institute, West Virginia

\section{Allyssa Sobey}

Thesis submitted to the College of Arts and Sciences at West Virginia University

In partial fulfillment of the requirements for the degree of

Master of Arts in Geography

Bradley Wilson, Ph.D., (chair)

Ann Oberhauser, Ph.D.

Daniel Renfrew, Ph.D.

Department of Geology and Geography

Morgantown, West Virginia

2014

Keywords: environmental justice, oral history,

Bhopal disaster, social movements

Copyright 2014 Allyssa Sobey 


\section{ABSTRACT \\ Long Exposures: environmental racism and activism in Institute, West Virginia}

\section{Allyssa Sobey}

On December 2, 1984 a lethal cloud of Methyl Isocyanate (MIC) - a key chemical ingredient used to manufacture agricultural pesticides- leaked from a Union Carbide plant in Bhopal, India. The release covered approximately nine miles and consisted of 40 tons of MIC, causing an estimated 2500 immediate fatalities and more than 10,000 deaths within a week of the event. While the Bhopal disaster captured global headlines and sparked transnational anti-toxics and environmental justice movements, the largest production and storage facility for MIC in the world was located in the Institute Industrial Park- just a few miles west of Charleston, West Virginia. Situated within several predominantly African American communities, the Institute Industrial Park had been producing noxious chemicals to manufacture pesticides since the early 1960s. The Bhopal disaster reinvigorated a local anti-toxics group in Institute- People Concerned About MIC (PCMIC) - that was able to successfully eradicate MIC from the Institute plant. Rooted in discussions of scale, environmental justice and locational conflict literatures, and the role of complex structural processes, this paper explores the geographic context through which PCMIC activists form and frame their grievances. Using Bullard's foundational work, Dumping in Dixie, as a point of departure for discussion, this project aims to understand how activists within PCMIC frame their struggle through an analysis of protest materials, public documents published by PCMIC, and several oral histories provided by key informants. 
Table of Contents

$1.0 \quad$ Introduction ................................................

1.1 Thesis

Outline............................................4

2.0 Literature Review.......................................7

2.1 Geography and Environmental Justice............12

2.1 (a) Distributive Justice..............................13

2.1 (b) Procedural Justice............................15

2.1 (c) Environmental Racism......................15

2.1 (d) NIMBY and Locational Conflict .................18

2.2 Placing Environmental Racism: Dumping in Dixie

Revisited....................................................22

3.0 Case Study

3.1 Institute, WV ...........................................25

3.2 People Concerned About MIC.........................28

4.0 Methodology .....................................................31

5.0 Analysis..................................................38

5.1 Diagnostic framework......................................40

5.1 (a) the problem.........................................41

5.1 (b) who's to blame.................................47

5.2 Prognostic Framework................................51

5.3 Motivational and Scalar Frameworks (the power of place)........................................................59

5.3 (a) revisiting Institute, $W V$..........................63

6.0 Discussion...................................................68

6.1 Environmental injustice in Institute...................70

7.0 Conclusion...................................................77

8.0 Appendix.................................................79

9.0 Bibliography.............................................82 


\subsection{Introduction}

On December 2, 1984 a lethal cloud of Methyl Isocyanate (MIC) - a key chemical ingredient used to manufacture agricultural pesticides- leaked from a Union Carbide plant in Bhopal, India. The release covered an area of approximately nine miles and consisted of 40 tons of MIC. Toxics penetrated the homes of thousands of citizens causing extreme vomiting, temporary and permanent blindness, skin rashes, and respiratory damage. The MIC leak in Bhopal caused an estimated 2500 fatalities that evening and more than 10,000 deaths in the immediate aftermath of the event. Hundreds of thousands more were exposed and families continue to suffer from severe birth defects and chronic illness (Cutter, 2006). According to doctors in New Delhi, an estimated ten people die each week because of complications from the immediate exposure or contaminated drinking water linked to the un-remediated toxic site.

While the Bhopal disaster captured global headlines and sparked transnational anti-toxics and environmental justice movements, the largest production and storage facility for MIC in the world was located in the Institute Industrial Park just nine miles west of Charleston, West Virginia. Originally constructed for rubber manufacturing during WWII, the Institute Industrial Park has since served as a global hub for agrochemical industry giants such as DOW, Rhone-Poulenc AgCo, Union Carbide Corp and most recently Bayer CropScience (Woomer, 2012). Bayer CropScience purchased the industrial park in 2002 and today it houses several other chemical companies including DOW, FMC, and Praxair within its 460-acre facility. 
For 30 years following the Bhopal disaster, environmental advocates, labor and neighborhood rights groups fought hard against multinational chemical companies and state officials to enforce safety standards and educate the public on the dangers of exposure to MIC and other deadly toxics produced in the chemical valley of West Virginia. Although many of these groups successfully opened up lines of communication between residents and the chemical corporations, suffering continues in Institute, WV. Activists in the valley have seen little progress at the local and state level to combat the problem, even in the face of hundreds of reported and unreported toxic exposures.

On August 28th, 2008, however, an explosion within Institute Industrial Park's Methomyl-Larvin unit killed two employees and sent a fireball into the air that landed several yards from an aboveground MIC storage tank. The Chemical Safety Board ${ }^{1}$ reported that if the MIC tank had been compromised, a release of approximately 13,700 pounds of MIC would have enveloped 3.9 square miles of surrounding communities, affecting nearly the entire population of Charleston (Ward, 2011). The "close call" reinvigorated a sense of fear, mistrust, and uncertainty associated with the chemical industry in Charleston, WV and awakened a dormant local anti-toxics movement born in the immediate aftermath of the Bhopal disaster, People Concerned about MIC (PCMIC).

Following the 2008 explosion at Institute Industrial Park, a change in the group's leadership, and the ailment of several key members, there were dramatic shifts in PCMIC's organizing techniques and tactical strategizing. These transformations led to different approaches to chemical safety in the valley and altered how the group framed environmental injustice in Institute. These different frameworks vary over time and

\footnotetext{
1 The Chemical Safety Board is an independent federal organization responsible for investigating the causes of industrial chemical accidents throughout the US.
} 
reflect the experiences and values of individuals in positions of power within the group. However, most commonly, the Bhopal disaster is referred to as the catalyst for change the reason for the inception of the group. Using Bullard's pivotal piece Dumping in Dixie as a point of departure for examining locational conflict in Institute, WV, this thesis investigates framework shifts within PCMIC through activist perspectives in order to understand the movement on its own merits, distinct from the catastrophe in Bhopal. I accomplish this through a framework analysis of oral histories provided by founding members of PCMIC.

In so doing, my project has three main conclusions. First, I return to Bullard's critical work in Institute to provide new perspectives on locational conflict surrounding MIC production and storage in Institute, WV. I am able to confirm Bullard's work in the following ways: air pollution continues to be the number one identified issue in need of resolution; activists identify racism as the reason why the MIC plant was located in Institute; and I am able to extend his exploration of activist dynamics in Institute by identifying to whom activists attribute blame for their suffering. Most importantly, I am able to confirm that environmental racism remains a critical framework of analysis for locational conflict, as the following two findings highlight.

Second, through oral histories and archival work, my research uncovers importance of the racialized creation of Institute, WV - an unincorporated township with limited access to democratic and procedural processes. The racial historical significance of Institute effectively shifts the location of conflict away from MIC production and onto Institute itself. Examining Institute's locational conflict through the lens of environmental racism reveals that the narrative of PCMIC is primarily concerned with protecting 
community health, which relies heavily on the unincorporated status of the township. Community health, as discussed within the analysis section of this paper, refers to the ability to uphold social and cultural values commonly shared within a community.

Lastly an inconsistency between two of my framework analyses demonstrates the dangers of "scaling up" PCMIC efforts: the negligence of Institute's racialized past. As demonstrated by PCMIC in Institute, scaling up environmental justice movements can dilute the impacts long-term structural processes have on the struggles of subaltern groups in particular places. A useful tool for creating awareness, scaling up has redirected PCMIC's concern with institutionalized racism and broader class struggles to the spectacle of Bhopal, adopting the undesirable characteristics of classic NIMBY movements (displacing threats rather than addressing the structures that perpetuate the need for said threats). PCMIC's shift from issues of long exposure to facility siting and spectacle-esque catastrophe bolster Bullard and Lake's critical responses to NIMBY critiques (discussed in detail below) and require a more careful examination of the term 'NIMBY'.

\subsection{Thesis Outline}

The thesis proceeds in seven core sections. The first will be a review of environmental justice literatures subdivided into three sections: geography and environmental justice; NIMBY and locational conflict; and a review of Bullard's Dumping in Dixie. The first part of my literature review, geography and environmental justice, is a general overview of environmental justice that includes the basic definition and components of the approach. Additionally, this section will discuss the varying ways geographers have studied environmental justice throughout the past few decades. The 
second part of the literature review, NIMBY and locational conflict, is again a general review of terminology and common applications of these ideas in the discipline of geography. Lastly, my review of Dumping in Dixie will explore Bullard's formative discussions of environmental racism and how it influenced contemporary environmental justice research. More specifically, I highlight how Bullard's discussions of place will be used strategically for the analysis of my own research.

Following the literature review, I outline the methodological and theoretical approach to my study. First I explain Pulido's subaltern environmental justice framework and how it enhances Bullard's environmental racism by re-centering knowledge production to those occupying the margins - the subaltern. Subaltern environmentalism is in fact a method of analysis for my data, collected via recorded oral histories with six key informants. These informants are key members of PCMIC, recruited via criterion sampling. Data is supported by the use of archival research, as well as an in-depth media analysis of the state capitol newspaper, the Charleston Gazette. It is within this section of my paper that I explain the importance of how situated knowledges is critical for deflecting any critiques of oral history methodologies. Likewise, this section highlights the pros and cons of using oral histories as a core data source.

After the review of my methodology, I provide a summary of my case study. This section of my project is unique because it is split into two parts, one of which is located within the analysis section of my thesis. First, I provide a brief historical analysis of the chemical industry in West Virginia and the emergence of 'chemical valley'. Afterword I provide a summary of People Concerned about MIC: the origins of the group and highlight several of their main strategies for achieving success. Later I provide a more in- 
depth and nuanced review of Institute as provided by my informants within the analysis section of this paper. For reasons explained more clearly in my analysis, many of my informants use the history of Institute as a tool for motivating community members to join PCMIC. Thus, I felt it necessary to include this history of Institute within the motivational framework analysis.

Following the case study of Institute and PCMIC, I begin my framework analysis. This section begins by defining framework analysis and is then split into three subsections. The first section is the diagnostic framework. This framework pulls quotes from the collected oral histories in order to highlight what individuals identify as the core issues they mobilize around, and who they blame for the existence of those issues. These data are mainly collected from responses to questions such as "why did you become involved with PCMIC?". The second framework of analysis is the prognostic framework. This framework identifies core strategies for achieving justice and solving the issues identified in the diagnostic framework. The third section of framework analysis is a combination of two different frameworks: the motivational and scalar frameworks. This framework reviews the rhetorical strategies employed by PCMIC in order to attract new activists. Often, these rhetorical strategies call upon place-based attachments in order to motivate individuals. Hence, the second overview of Institute is included in this section, because its story is often used to attract activists and frame PCMIC's grievances.

Lastly, the discussion and conclusion sections of my thesis follow the analysis of my data. These sections summarize key findings from my framework analyses and explore their theoretical implications. In particular, I draw on the significance of place in 
locational conflict and its importance for shaping the dynamics of PCMIC. Following these discussions is a brief conclusion that introduces suggestions for future work.

\subsection{Literature Review}

The origins of the modern day Environmental Justice movement can be traced to a series of protests in Warren County, North Carolina in 1982 wherein a community of primarily African Americans fought the siting of a hazardous waste facility in what became known as the catalyst of environmental justice grassroots efforts (Martinez-Alier et al., 2014; Mohai, P., Pellow, D., Roberts, J.T., 2009). The actions of activists in Warren County attracted national media attention and spurred investigations regarding the demographic composition of communities suffering from hazardous facilities. Shortly thereafter, a series of quantitative studies revealed "people of color and low-income populations have suffered from greater environmental harm from waste sites, incinerators, refineries, transportation infrastructures than white and well-off communities" (Martinez-Alier et al, 2014 p. 21).

Today, the environmental justice movement largely coheres around the principal that, "all people and communities are entitled to [the] equal protection of our environmental, health, employment, housing, transportation, and civil rights laws" and that people should collectively oppose "toxic colonialism, environmental racism, and the international toxics trade at home and abroad" (Walker and Bulkeley, 2006; Bullard, 1996, p. 48; Bullard, 2008, p. 17). With roots in the Civil Rights movement, environmental justice efforts emerged from low-income and minority populations in an attempt to raise awareness about systematic processes that single out specific 
communities to bear the brunt of harmful yet "necessary" facilities (Bullard, 1990; Popper, 1985; Pulido, 1990).

As such, environmental justice movements are mostly concerned with uncovering structural injustices in an effort to address environmental degradation and social inequality simultaneously, critiquing the platform of the traditional environmentalism movement for privileging non-human actors (Bullard, 1990; Martinez et al, 2014; Mohai, Pellow, Roberts, 2009; Pulido, 1990 \&1996). Traditional Environmentalism was popular within the late nineteenth century throughout the mid twentieth century in the United States. Generally characterized by large organizations such as the Sierra Club, traditional environmentalism was primarily interested in wilderness preservation and species conservation. Traditional environmentalists often approach "nature" and the environment as being strictly non-human, possessing transcendental qualities (Castree 2005). Today, traditional environmentalism is considered a privileged movement, sustained by middleclass white populations with the luxury to be able to worry about environmental aesthetics, rather than surviving.

Following traditional environmentalism came radical environmentalism in the late 1960s and early 1970s. Radical environmentalism moved away from voyeuristic approaches to nature and the environment and began to incorporate people into the landscape. Rachel Carson's pivotal book Silent Spring is often cited as the catalyst of the modern environmental movement against toxics and pesticides. Thus began an examination of the dialectic relationship between humans, the environment, and landscape production. Although environmentalism (according to many) remains 
fundamentally flawed, the environmental justice movement has borrowed several tenants of environmentalism.

Both environmental justice and radical (or mainstream) environmentalism are considered to be New Social Movements (NSM). NSMs emerged in the post-Fordist era and experienced popularity (within the US) in the 1960s. The Civil Rights, Queer, Feminist, and Youth movements are all popular examples of NSMs that emerged in this time period (Edelman, 2001). New Social Movements have a set of generally agreedupon characteristics. First, NSMs are primarily concerned with quality-of-life and the expansion of rights as opposed to strictly class-based or economic movements prevalent prior to and throughout the 1970s (Edelman, 2001; Pulido, 1990). Second, NSMs are less concerned with large-scale transformation, and are centered more on the "every day" and local struggles of individuals (Edelman, 2001; Pulido, 1990). Lastly, NSMs function outside the confines of government or corporate systems, such as labor unions or political parties. They are typically less hierarchical; rather they attempt to be more horizontally organized (Edelman, 2001; Pulido, 1990).

However, there are two key NSM paradigms that have conflicting frameworks for understanding and defining NSMs. The first believed that in postindustrial cultures, class was no longer the only indication of power and "other social cleavages become more salient [...]" (Edelman, 2001 p. 288). This framework viewed NSMs as identity-based, wherein quality of life was linked to several cultural, social, political, and economical phenomena and values. The second NSM framework focused on resource mobilization and strategic approaches to organizing (Edelman, 2001). This viewpoint understood "social movements as interest group politics and understood success primarily as the 
achievement of policy objectives, rather than in relation to broader processes of cultural transformation" (Edelman, 2001 p. 289). These two frameworks for understanding NSMs echo shifts that began to take place within the environmental justice movement in the early 1990s. Previously, environmental justice was achieved through policy changes or quantifiable measurements such as relocating a toxic facility or reducing harmful emissions. Today environmental justice is largely linked to non-quantifiable measurements of justice often related to identity politics (primarily race and gender). The two most prominent examples of this paradigm shift within environmental justice/NSM frameworks are environmental racism and subaltern environmentalism.

The differences between mainstream environmentalism and environmental justice are much more nuanced than many understand. In fact Pulido (1996) asserts that by referring to race/racial tensions as their primary difference, we leave behind many other important aspects of what defines environmental justice. In order to draw on these refined discrepancies, Pulido offers the subaltern environmentalist approach, defined and discussed in more detail in the section to follow. In short, Pulidio (1996) outlines the key differences between traditional environmentalism and subaltern environmentalism as being rooted in the methods for achieving change, the economic status of movement actors, and the different ways these two groups approach identity as it is linked to the environment.

Traditionally, environmentalists have been able to identify with those occupying positions of power - this is because those who typically participate within the mainstream environmental movement occupy the middle class and work primarily in the service sector of the economy. Due to their relationship with those who manage or run 
corporations and businesses, mainstream environmentalism often relies on lobbying and maneuvers within existing power structures in order to achieve change. Alternatively, subaltern environmentalism is fundamentally in opposition to the status quo and is founded on goals aimed at redistributing power. Because of their position within class structures, mainstream environmentalists are not directly impacted by the environmental controversy at hand whereas subaltern environmentalism stems from those directly impacted by said environmental issue (often the result of working within the primary and manufacturing sectors of the economy). In turn, mainstream environmentalists typically support or stand in solidarity with those being directly impacted (the subaltern). Lastly, although both movements are typified as NSMs they each approach identity very differently. Environmental Justice (more specifically, subaltern environmentalism) is concerned with quality of life as it is linked not only to the status of the physical environment, as mainstream environmentalists understand it, but as it is linked and intertwined with community, culture, class, and economy (Pulido, 1996).

The schism between mainstream environmentalism and environmental justice highlights the importance of race and class within these two movements. However, Martinez-Alier et al (2014) note that for many environmental justice organizations, "social class comes second to issues of racial discrimination [...]" (p. 21). As discussed in the analysis sections of this paper, PCMIC activists indeed lean more towards framing their struggle through a racialized lens as opposed to a class-based lens. It is important to note, however, that both race and class do inform People Concerned. The issue of class is of particular importance in Appalachia, as it dialectically shapes the uneven distribution of wealth and environmental burdens throughout the state and reproduces poverty. 
The following section is a review of environmental justice literatures and how they will inform my research. I begin with explaining how environmental justice is inherently a geographic endeavor due to the pervasiveness of place and scale within environmental justice research. I follow with a review of each of the four cores of environmental justice literature: distributive injustice, procedural injustice, environmental racism, and NIMBY and locational conflict. I conclude this section with a critical review of Bullard's Dumping in Dixie and outline how I will use his work in order to explore MIC production in Institute, WV.

\subsection{Geography and Environmental Justice}

Over the past three decades, geographers have made significant contributions to social movement research, particularly with a focus on environmental justice movements (Miller, 2000; Marston, 2003; Nicholls, 2007). As stated above, environmental injustices are the direct result of complex structural and decision-making processes that lead to the siting of noxious facilities and uneven distribution of environmental burdens (Bullard, 1990, 2002; Schlosberg, 2004; Schroeder et.al, 2008; Walker and Bulkeley, 2006). These environmental burdens disproportionately affect communities of color and low socioeconomic status across varying scales and occur unevenly across space (Bullard, 1990). The uneven distribution of environmental burdens takes shape in many different forms and does not adhere to political boundaries. Examples of these unevenly distributed burdens include waste disposal, chemical emissions, and environmental degradation. Increasingly these burdens are surpassing international borders, especially with the 
popularity of Multi National Corporations (MNCs) (Dembo, D., Idas, C.J., Kadwani, A., Morehouse, W., 1988; Guillette, E., 2008).

Geographers have demonstrated the trans-national relevance of environmental justice through an examination of international commodity chains. As neoliberal policies seek cheap, resource -rich environments abroad for the production of commodities managed, consumed, and disposed of elsewhere, the distribution of environmental burdens becomes increasingly globalized and fluid (Dembo, Idas, Kadwani, Morehouse, 1988; Faber, 2008; Guillette, 2008; Renfrew, 2011). In turn there is an expressed desire for environmental justice movements to organize internationally, problematizing the militant particularisms of grassroots efforts (Harvey, 1996; Hutchison, R., 2012; Walker and Bulkeley, 2006).

Similarly, the scalar fluidity of place is increasing alongside globalization and neoliberal investments. Due to this "glocalization" of place, and the place-based nature of environmental justice grassroots efforts (combating a specific facility, protecting a landscape with cultural and historical values), grassroots organizations are experiencing difficulties framing their grievances within the appropriate scalar contexts (Swyngedouw, E. and Heynen, N.C., 2003). Environmental injustice, in other words, is fundamentally geographical. There are four core approaches to environmental justice research in geography: distributive justice, procedural justice, environmental racism, and locational conflict. A brief review of each follows.

\section{1 (a) Distributive Justice}

Distributive injustice refers to the unequal distribution of environmental benefits and burdens (Schlosberg, 2004). Often distributive injustice is explored via the 
quantitative measurement of exposure; that includes taking samples in order to gauge contamination in water, soil, or air samples. Additionally, many health studies are considered to lay the groundwork for making claims about how unevenly toxics are distributed among certain populations. In geography, distributive injustice can be measured by distance to a toxic facility. In fact distributive injustices serve as the crux of environmental justice efforts - proof that there exists a larger, structural issue.

However, in recent years scholars interested in deconstructing the larger processes that lead to the uneven distribution of environmental burdens have critiqued distributive justice rhetoric. Perhaps the most poignant critique of distributive injustice comes from Young (1990) who highlights the flaws of this approach through the distributive paradigm. Within the distributive paradigm Young (1990) explains that distributive injustice is problematic for two reasons: First, distributive justice is often used to explain the uneven distribution of material goods, including resources, money, property, etc. Consequently, distributive rhetoric inherently links individuals and their worth to the amount of goods they possess. However, justice extends beyond material wealth and includes "nonmaterial social goods such as rights, opportunity, power, and self-respect" (Young 1990, 16). Second, nonmaterial goods such as culture and power rely on fluid interactions and relationships between individuals. Young goes on to say that, The distributive paradigm implicitly assumes that social judgments are about what individual persons have, how much they have, and how that amount compares with what other persons have. This focus on possession tends to preclude thinking about what people are doing, according to what institutionalized rules, how their doings and havings are structured by institutionalized relations that constitute 
their positions, and how the combined effect of their doings has recursive effects on their lives. (Young, 1990, p. 25)

The above quote stresses a need to first, value nonmaterial goods such as culture.

Secondly, it calls for scholarship that examines the larger structural issues that make distributive injustices possible.

\section{1 (b) Procedural Justice}

Procedural justice refers to a community or individual experiencing limits with democratic decision-making bodies and practices that affect the degree to which communities are exposed to toxics (Bullard, 2008; Schlosberg, 2004; Schroeder et.al, 2008; Walker and Bulkeley, 2006). Investigating procedural injustice is centered on deconstructing all of the differing power struggles within which grassroots movements become contextualized and how they navigate them - these systems include race, class, gender, capitalism, uneven development, and others The shift of focus from distributive to procedural injustices marked a newfound interest in understanding environmental justice from a more holistic approach that considers the complex processes that create inequality, rather than studying temporary expressions of inequality (Lake, 1993).

\section{1 (c) Environmental Racism}

Environmental racism, an area of particular concern for this study, examines how socio-economic status and race/ethnicity impact the uneven distribution of environmental burdens, democratic decision-making processes and social mobilization. Environmental racism refers to how race and ethnicity, compounded with socio-economic status, leads to the unbalanced representation of communities of color suffering from environmental 
degradation and poor quality of life due to proximities to toxic facilities (Bullard, 1990; Pulido, 1996). Environmental racism, as defined by Robert Bullard, is

Any policy, practice, or directive that differentially affects or disadvantages (whether intended or unintended) individuals, groups, or communities based on race or color. Environmental racism combines with public policies and industry practices to provide benefits for whites while shifting industry costs to people of color $[\ldots]$ the question of who pays for and who benefits from the current environmental and industrial policies is central to this analysis of environmental racism and other systems of domination and exploitation. (Bullard, 1990, p. 98)

Environmental racism is a key framework through which all of my informants understand their struggle with the Institute Industrial Park; therefore a more nuanced understanding of the link between race and environmental injustice is necessary. Initially environmental justice studies were primarily concerned with measuring and determining which communities were disproportionately affected by environmental burdens. In many of these cases, race was often found to be a defining factor. However, Pulido (2000) critiques these misconceptions of race and racism as harmful because:

By reducing racism to a hostile, discriminatory act, many researchers, with the notable exception of Bullard (1990), miss the role of structural and hegemonic forms of racism in contributing to such inequalities (Pulido, 2000, p. 12).

Referring to racism as an intentional act, rather than a structural inequality, requires that communities provide acceptable proof that race explicitly contributed to any decisionmaking process leading to the siting of a noxious facility. Discourse surrounding 
acceptable proof refers to the types of knowledge that are valued - most often through the hegemony of Science (McNeil, 2011). Pulido asserts that we must not fetishize the siting processes of an individual facility because hegemonic powers do not always discriminate intentionally.

In her landmark book, Environmentalism and Economic Justice (1996), Laura Pulido challenges the approaches of the traditional mainstream environmental movement using environmental racism as her primary lens of analysis. In order to address complicated issues of systemic racism disguised as "white privilege" in the mainstream environmental movement Pulido offers an alternative approach to addressing issues of distributive and procedural injustice by employing the concept of subaltern environmentalism. Subaltern environmentalism counters mainstream environmentalism by claiming that the discourse of environmentalism separates issues of livelihoods, racism, and class as being isolated from issues of environmental preservation. Pulido argues that economic and civil rights struggles are inherently aimed at tackling environmental issues which are embedded within complex identity and historical inequalities, precisely the kind of distributive and procedural inequities that have lead to the uneven distribution of land, resources, and pollution (Pulido, 1996). ${ }^{2}$

For subaltern groups, environmental, economic, and social injustices are enmeshed and interconnected, "environmental quality is no different from other social issues in that racially dominated groups encounters them within the context of subordination" (Pulido 1996, p. 17). This intersectional concept of domination draws on situated and indigenous knowledges. As a result, subaltern environmentalism heavily

${ }^{2}$ Additionally, the EJ theoretical framework is more heavily focused on income and racial inequalities and often neglects the role gender has on the susceptibility of an individual or community at risk (Buckingham and Kulcur, 2009). 
relies on positionality and is a particularly useful tool for scholars interested in understanding grassroots resistance from the perspectives and experiences of individual activists. Positionality as a tool for environmental justice activism is important because individual activists experience environmental issues from different structural positions that require separate solutions and courses of action (Egan, 2002; Pulido, 1996).

\section{1 (d) NIMBY and Locational Conflict}

Geographers also tend to approach environmental justice through the study of place-based locational conflicts. Locational conflicts are broadly defined as conflicts that emerge when individuals or groups perceive that they are unfairly and negatively impacted by a location-based or siting decision (Lake, 2001). The roots of locational conflict research can be traced to conflicts over Locally Unwanted Land Uses (LULUs). Groups and individuals that organize opposition movements against the perceived negative effects of LULUs are often referred to as NIMBY movements (Not-In-MyBackyard) (Lake, 2001). NIMBY movements and locational conflicts in general, are typically dedicated to the relocation of LULUs and function within the geographic boundaries of the smallest scale decision-making body - in part due to resource availability (Kurtz, 2003; Lake, 1993). However locational conflict differs from NIMBYist sentiment in that locational conflicts are very much concerned with understanding the structural processes that lead to the initial siting of LULUs.

In turn, scholars are critical of NIMBY movements because they are viewed as limited solutions to much more complicated issues. NIMBYists are characterized as being irrational and reactionary in that they advocate the continual displacement of environmental hazards rather than a) fighting for their complete eradication or b) 
combatting structural and procedural injustices (Lake, 2001; Wapner 2004). Because NIMBY movements are likely to use immediate geographic contexts as a point of contention when expressing grievances (often resulting in temporary displacement of environmental toxics), NIMBY movements are accused of simply relocating noxious facilities. The effects of displacement, the relocation of environmental burdens, manifest both spatially and temporally. In fact, the hazardous facilities displaced by NIMBY groups "in almost all cases, flow from the affluent and privileged to the poor and underprivileged" (Wapner, 2002, p. 26). Through the physical relocation of a facility and the destruction of landscapes left for future generations to alleviate, it is perhaps clear why NIMBY movements are considered to be unfavorable (Wapner, 2002).

However, Lake asserts that the political decision to brand NIMBY movements as selfish and reactionary is carefully executed in order to remove any skepticism from capital itself (Lake, 1993).

Siting hazardous waste incinerators, for example, constitutes a locational solution to an industrial production problem $[. .$.$] the facility siting strategy concentrates$ costs on host communities, as compared to the alternative strategy of restructuring production so as to produce less waste. (Lake, 1993, p. 8)

Local and national authorities, and corporations often package LULUs, as opportunities for economic advancement and modernity needed in specific areas. As such, NIMBYists are blamed for the economic decline of regions in need of opportunity when they successfully remove or reject LULUs. Lake (1993) posits that the presence of noxious facilities is not necessarily beneficial for the economic goals of the immediate communities; rather LULUs benefit the goals of capital. 
Despite critiques, locational conflicts, or place-based movements, continue to be important because site-specific movements interact with small-scale urban units -the most basic unit of structural power (Lake, 2001). Territory and place are what create the relational qualities that enable collective action. Common geographic reference points facilitate strong connections between individuals that strengthen oppositional campaigns, even when risk increases (Nicholls, 2007). Movements become rooted in the places where the lives of activists intersect with uneven development and various power structures. Because of the immediate geographic context of many movements, local activist strategies become aimed towards immediate decision-making bodies (Gregg and Gamble, 2012; Nicholls, 2007; Sze and London, 2008).

However, applying finite geographic borders to cities and communities is increasingly difficult due to the "multi -layered networks of local, regional, national, and global connections" (Swyngedouw and Heynen, 2003, p. 899). The increasing mobility of capital, rapid deindustrialization and presence of multinational corporations has in effect diluted the powers of locally based decision-makers to which NIMBY movements appeal (Fischer and Smith, 2012; Schroeder et.al, 2008). The relocation and redistribution of power is critical because, as mentioned above, movements often function within the boundaries of the most appropriate and accessible decision-making body in order to more efficiently advocate change (Kurtz, 2003; Lake, 1993).

Nevertheless, NIMBY groups are still likely to use their locational context as a reference point when framing their grievances, more specifically a neighborhood unit (Kurtz, 2003). The neighborhood can be defined as a district within an urban area commonly characterized as being mostly residential (Gregory et.al, 2009). Additionally, 
neighborhoods tend to be relatively homogeneous culturally, ethnically, and economically. Often members belonging to the same neighborhood hold shared values and expectations of what others within the neighborhood support; subsequently community-based activist organizations are not only established based on specific territory, but also common interests (Martin, 2003). Place and location are critical to the formation of collective-action frameworks because "potential recruits are more likely to perceive that opportunities outweigh risks when the spatial imaginaries used to frame a social movement are consistent with their own" (Nicholls, 2007), hence NIMBY movements may tend to reflect the grievances of people within particular places.

Place, therefore, is of vital importance to environmental justice struggles. Locational conflicts occur in places where systemic forms of oppression collide with the historical, material and cultural contexts (Bullard, 1996; Escobar, 2008; Pulido, 1996). Increasingly geographers have studied the linkages between identity construction and place and how that may impact the dynamics of social activism. Place serves as the epicenter of where culture, history, and identity inform one another. Places are a complex dialectical exchange between global economic systems, unique histories, and cultures (Smith, 2008) and often are the result of uneven development. In turn, subaltern environmental struggles are often referred to as place-based struggles (Escobar, 2008). It is important to note, however, that places are often racialized. Bullard and Escobar both highlight the role of race in the creation and development of their various case study sites. Bullard, in particular, discusses the role of slavery in the US South, while Escobar is primarily concerned with colonialism and slavery on the Pacific coast of Colombia. Both sets of case studies reflect on these racial and colonial pasts, and how they have 
influenced how places are made, how individuals identify with places, therefore affecting how people therefore define their environmental and political struggles.

The relationship between race and place for my case study is central to my analysis of the locational conflict in Institute, WV. The decision to site the Institute Industrial Park chemical facilities was based on a series of (intentional and unintentional) decisions to locate the plant in a primarily African American township in WV. Second, the rich historical and cultural context of Institute, WV adds layers of complexity to the siting-based decision, this informs the development of PCMIC.

\subsection{Placing Environmental Racism: Dumping in Dixie Revisited}

Since the 1980s, environmental justice research has shifted from an initial interest in quantitatively measuring the distribution of environmental degradation across space, to how environmental burden jumps scale via the circulation of toxics and the different scales at which remediation and regulation takes place (Kurtz, 2003). In light of this shift, much research is now dedicated to deconstructing the decision-making processes that lead to the unequal distribution of burdens. Though the ability to demonstrate unfair exposure and facility siting using measureable proof remains a critical strategy in environmental justice campaigns. Understanding how African American communities combat facilities and the processes that lead to their siting locations, however, has been limited (Bullard, 1990). In his formative piece, Dumping in Dixie, Bullard uses the lens of environmental racism to explore five in-depth case studies of black environmental activism (including Institute, WV) located throughout the US south in order to highlight the role of black environmentalism in the national environmental movement. 
Throughout the text, Bullard critiques the larger structural processes that lead to the uneven distribution of environmental burdens. He explores how land-use decisionmaking processes have led to increased risk for African American communities, expressed via the disproportionate exposure to noxious facilities. Ultimately, these overarching structural processes lead to the creation of highly racialized places that lack access to democratic and procedural justice- commonly referred to as unincorporated townships - resulting in the inability to prevent LULUs. In so doing, he comments upon the significance of urban-planning policies and the destructive nature of NIMBYist labels applied to African American grassroots efforts. In order to combat these structural inequalities, Bullard proposes an environmental equity movement that applies the strategies and perspectives of black environmental grassroots efforts and re-centers the popularized environmental movement to the victims. Bullard asserts that "most environmental disputes revolve around siting issues" which often attract the attention of outsider activists and neglect communities already living within close proximity to LULUs (mostly African American communities). Consequently, the purpose of his study is to understand how communities affected by LULUs dispute these facilities through an examination of activist perspectives.

Using large-scale quantitative household surveys supplemented with in-depth unstructured interviews, he frames the issue of unfair siting of unwanted land uses (LULUs) in African American communities through discussion of environmental racism. He asserts that environmental racism is not only critical for understanding how environmental inequalities emerge, but also for understanding how black environmental grassroots groups strategize to combat these inequalities. Therefore, the perspective of 
activists within these communities is critical for creating a more effective and inclusive environmental movement. Bullard's study was primarily interested in how activists defined (or framed) their struggles and attempted to outline how problem identification and strategic approaches differed across his five case studies. In order to do so, Bullard organized and analyzed his data according to five broad categories: issue crystallization and focus, leadership type, oppositional tactics, resolution mechanisms, and outcomes.

Through his analysis of these five frameworks Bullard finds that the most common types of oppositional activities among citizens in Institute (in order) were: signing a petition opposing facility siting, attending public hearings, telephoning an influential person, attending a meeting in someone else's home and, discussing the matter at a church meeting (Bullard, 1990, p. 92). Bullard concludes his study with a call-toaction that outlines specific tactics and goals for achieving an inclusive environmental justice movement.

After his final analysis of the five case studies, Bullard purports that environmental racism not only guides the siting of LULUs, but also shapes how the current environmental movement continues to ignore procedural and structural injustices as demonstrated by a lack of POC in positions of power within the current movement, and the pervasive critiques of NIMBY attitudes (as discussed above). Bullard calls for an environmental equity movement that understands how black grassroots groups organize and that "rests upon an ethical analysis of strategies to eliminate unfair unjust, and inequitable conditions and decisions" (Bullard, 1990, p. 118).

While Bullard's work provides insight to the overall concerns of citizens living in Institute, my work explores the specific tactics and dynamics of People Concerned About 
MIC. By tweaking the frameworks applied by Bullard for my own work, and further emphasizing the perspective of the individual via oral histories, my project highlights how environmental justice activism and locational conflict in Institute can be better understood through the continued lens of environmental racism.

\section{Case Study}

\subsection{Institute, West Virginia}

The production of MIC in Institute, WV is embedded within a history of exploitation and degradation. Appalachia has a wealth of natural resources, yet suffers from extreme poverty due to an economy closely tied to resource extraction and manufacturing, a place where "local power is constrained by the economic dependence on the absentee employer - big decisions [...] made hundreds of miles away by wealthy members of the ownership class" (Hutchison, 2012). Traditionally, these economic descriptors are used to refer to developing nations within the Third World. For these regions, place is not only defined by their cultures, histories, or unique flora and fauna, rather how these cultures, histories, and landscapes have been co-opted by capitalism in order to produce monetary value (Fischer and Smith, 2012). Recently, environmental justice scholarship has begun to critically examine how the histories of internal colonialism in the United States, and its relationship to global capitalism, has produced spaces of environmental injustice and conflict. These processes and structures create conditions that pressure marginalized populations to accept industries that are harmful to the environment for the sake of economic advancement (Holifield et.al, 2009). Appalachia has been one such region that suffers the present-day consequences of the harmful colonial-like practices of the coal and chemical industries. 
The Kanawha Valley in West Virginia is littered with dozens of chemical plants and refineries. The presence of these industries is rooted in a complex history of exploitation that can be traced to the fast-paced development of the Eastern coast of the US and harmful stereotypes of Appalachians. West Virginia's resource -rich land served as the physical gateway into the West during the early $19^{\text {th }}$ century. As such, the region offered a strategic advantage to extractive industries centered on exporting goods. Consequently, the resource-rich landscape fueled much of the growth of the nation. Because locals lacked an understanding of commodity and property values, companies were able to easily swindle Appalachians into selling their land for unfair prices (Gaventa, 1980). Thus, Appalachians became known as a non-confrontational, acquiescent, and powerless population (Gaventa, 1980). Even today these stereotypes affect national and international perceptions of the region, as demonstrated by the recent water contamination in Charleston, WV 2014 ${ }^{3}$. In turn, West Virginia is considered by many to be resource-rich and backwards - a place where capital is generated from both human and environmental exploitation, an internalized Other (Fischer and Smith, 2012).

Eventually, the coal and chemical industries became so prevalent that they were able to embed themselves within communities as an economic necessity - successfully becoming a part of local identity and leveraging their power in order to naturalize company policies, politics, and environmental degradation. Consequently, Appalachians suffer from identity conflicts rooted in a love and respect for the pristine mountainous landscapes, but also the need for stable income and regional economic prosperity. Thus

\footnotetext{
${ }^{3}$ Molenda, R. (2014, January 9). Thousands of Residents Warned to Not Use Water. Charleston Gazette. Retrieved from: http://www.wvgazette.com/News/201401090044. Kersey, L. (2014, January 20-related Hospital Admissions Rise. Charleston Gazette. Retrieved from: http://www.wvgazette.com/News/201401180073.
} 
Pulido's subaltern environmentalism, a New Social Movement with emphasis on identity politics, is an appropriate lens for examining grassroots environmental struggles in Institute, WV.

The presence of the chemical industry in West Virginia initially began as salt mining and manufacturing. Then, during WWII, the US commissioned a rubber manufacturing plant in the primarily African American community of Institute, WV to alleviate rubber shortages. The Institute Industrial Park plant was estimated to take ten years to construct; however the plant was built in ten months due to wartime pressures (Woomer, 2012). In 1947, Union Carbide bought the Institute plant, which neighbored an historically black college (West Virginia State University) and a rehabilitation center that housed roughly 1100 patients, and began using MIC in the early 1960s for the manufacturing of carbamate pesticides ${ }^{4}$.

Union Carbide's decision to purchase the Institute plant was the result of several complex historical and cultural processes, intersecting with neoliberal capitalism, and echoes the above-mentioned cultural misconceptions and strategic physical geographies that led industries to the region decades beforehand. Institute's primarily African American population and low socio-economic status created an opportunity for Union Carbide to situate themselves in a community they believed to be non-combative. However, as this project highlights, community members in Institute have actively fought

${ }^{4}$ MIC is used in the production process of two popular Carbamate insecticides: Aldicarb and Carbaryl, marketed as Temik and Sevin respectively. Although Carbamate pesticides are considered by many to be the most efficient pesticides available, their acute toxicity has made them quite controversial. Carbamate insecticides are primarily used on citrus, potatoes, and cotton crops and played a large role in the "green revolution" and the mass production of crops intended to subside poverty and hunger in developing nations. 
the plant's presence since the mid 1970s through the grassroots group People Concerned About MIC.

\subsection{People Concerned About MIC}

Immediately following the Bhopal disaster, community members in Institute became concerned that a catastrophe of similar proportions could occur in Institute. Shortly thereafter, several faculty members from West Virginia State College formed the activist community group, People Concerned About MIC (PCMIC). Originally, the group formed in order to create a unified front that demanded more efficient emergency evacuation routes and was dedicated to enhancing disaster preparedness throughout the community. As the core leadership of PCMIC shifted over the years, so too did their main goals and concerns. Although initially dedicated to emergency evacuation and safety procedures, PCMIC also adopted interests in air pollution, community health, human rights, and environmental justice more broadly.

Since the group's creation in early 1985, PCMIC has experienced ebbs and flows of activity primarily due to its strict reliance on volunteer work. In fact, PCMIC experienced almost a fifteen- year lull in activity between the mid 1990s and 2008. However, individuals maintained personal interest in the Institute plant and engaged in many small-scale efforts to combat the plant, such as reporting smells, noises to local authorities, calling and complaining to the plant manager, and attending public/community meetings. In 2008, after an explosion in the Methyl-Larvin unit ${ }^{5}$,

\footnotetext{
5 Staff. (Thursday, August, 28 2008). Blast rocks Bayer plant; Injuries reported; Area roads closed; Residents told to shelter in place. Saturday Gazette Mail. Retrieved from: http://www.wvgazette.com/News/Bayerexplosion/200904270376.
} 
PCMIC was able to organize under new leadership and successfully mobilize sixteen community members to sue Bayer CropScience. The intent of the lawsuit was to make sure that the recommendations of the Chemical Safety Board (following the 2008 explosion) were implemented, especially the Industrial Safety Model. As a result of the lawsuit, People Concerned was able to successfully eradicate MIC production and storage from the Institute plant - effective January 2012.

After the 2008 explosion PCMIC acquired an official 501 C-4 status under the new name, People Concerned about Chemical Safety. The name change is significant because it reflects the present concern with overall chemical safety in the Kanawha Valley, as opposed to Methyl Isocyanate - the core concern of PCMIC at its point of inception due to the temporal significance of the Bhopal disaster. Additionally, the group's $501 \mathrm{c}-4$ status legally protected the names of donors contributing to the lawsuit organized by People Concerned. Legal protection was important because in the aftermath of the 2008 explosion, Bayer CropScience quickly turned to political strategies aimed at "marginalizing" PCMIC and the Charleston Gazette. In a confidential document circulated internally at Bayer CropScience in December 2008, there is a list of Community Relations Strategies. An excerpt from this document reads,

Our goal with People Concerned About MIC should be to marginalize them [...] Treat them civilly so observers will not feel the need to come to their defense. Allow them to seem uncivil [...] Take a similar approach to The Charleston Gazette. For as many years as it has been in print, The Gazette has chosen to be anti-business and champion environmental activists' causes. Marginalize its effectiveness by treating its reporters with respect 
but avoid one-on-one interviews with them whenever possible. (Bayer CropScience Community Relations Strategy 12-29-08)

Part of the above-mentioned plan to isolate PCMIC included publically releasing the names of donors contributing to the lawsuit in order to turn plant workers against the group and its supporters.

Aimed towards enforcing chemical safety at the Institute Industrial Park, People Concerned has used community outreach in order to raise awareness and increase accountability among the chemical industries located along the Kanawha River. In addition to hosting meetings, attending other community planning meetings, and circulating small-scale publications about community health and safety, the group also leads individuals on "toxic tours". These toxic tours effectively immerse individuals within the toxic geographies of Institute by driving them through the various neighborhoods and institutions nearby the plant. While sharing personal stories of exposure and educating toxic tour-goers about Shelter-In-Place techniques, People Concerned provides interested individuals with an idea of the daily experience of living next door to a chemical plant. Toxic tours, as well as other strategies employed by People Concerned, are discussed in more detail in the prognostic framework analysis of this thesis.

\subsection{Methodology and Oral Histories}

The development of environmental justice movements combatting the siting of facilities rests in the motivating factors of individual activists. These motivations are 
largely rooted in identity politics and lived experiences. This project uses a critical environmental justice and subaltern environmentalism approaches, and qualitative methodologies in order to understand the origin and dynamics of the activist group People Concerned About MIC from the perspective of the activists.

The methodology originally designed for this project shifted during the process of conducting my semi-structured interviews. This organic shift in methodologies, from semi-structured interviews to oral histories, reflects the values and key concepts highlighted by Pulido in regards to subaltern environmentalism. These concepts include positionality and reflexivity, embodied experiences, the scale of the body, and situated knowledges. These concepts also serve as core tenets of feminist geographies. Positionality can be defined as locating oneself (the researcher) within the entanglement of power structures (Waitt, 2010). Reflexivity refers to the ability of the researcher to actively reflect on how our positions within these structures may affect how we interpret our data and write our analysis (Winchester and Rofe, 2010).

The relationship between oral histories, embodied experience, and situated knowledge is founded on the appreciation of individual informants and the nuances of their experiences. Generally, qualitative methodologies strive to conduct more inclusive, and holistic approaches to research that challenge the positivist notions of science based on "big" data. A large part of drawing on these subtleties and nuances rests on understanding that these phenomenon are the result of varying complex cultural and social structures embedded within society (Hay 2010). More specifically, qualitative research allows geographers the chance to uncover how these structures shape the experiences of individuals based on their positions within the myriad of these processes, 
but also deconstruct how the identities of individuals become intertwined with these systemic phenomena. These methods fill in the gaps left behind by the generalizations often made by quantitative studies and provide depth to a case study.

Past environmental justice studies, as discussed within my literature review, have been dedicated to the quantitative measurement of exposures. However as many environmental justice scholars have shifted from the quantitative measurement of exposure to uncovering procedural injustices, many researchers have begun to combine both quantitative and qualitative analysis in their research. One such example is Bullard's work in Dumping in Dixie. Bullard's approach to examining these case studies, including Institute, WV, uses a mixture of quantitative household surveys and unstructured interviews to gain a general understanding of black opposition movements in these sites.

Through a randomized sample of households, Bullard and his team conducted 101 survey questionnaires that gauged the differing concerns and level of participation in oppositional activities of community members. While Bullard's work provides insight to the overall concerns of citizens living within Institute, contributing to overarching discussions of black environmental activism across his five study sites, he does not explore these types of oppositional activities for PCMIC specifically. Rather, Bullard's work concerns the Institute community in its entirety. My thesis is dedicated to a more indepth understanding of People Concerned About MIC (PCMIC), using Bullard's study as a foundation. Dumping in Dixie was able to successfully provide a broad profile of activist-oriented ideologies in Institute as a township. I have used oral histories as a mechanism to explore the grassroots group PCMIC centered on the embodied exposures and perspectives of the activists involved. 
In order to fill in the gaps left behind by Bullard, I originally designed my methodology around conducting semi-structured interviews. My informants were selected based on criterion and snowball sampling techniques. The former is characterized by selecting a sample based off of a criterion each informant must meet: all of my informants had to have significant knowledge about the origins of PCMIC and its inner workings. Additionally my informants all served as board members, chairs, or were considered critical members of the group. Snowball sampling refers to when one key informant suggests other participants that could be included in a study. For example, I was able to contact the current leader of PCMIC and she put me into contact with several other persons of interest.

I prepared an intensive interview guide to take along with me during my interviews. This guide, 4 pages long, included 47 questions to help guide the conversation. However, when I arrived at my first two interviews I became completely overwhelmed and inundated with the stories my informants were sharing. Stories I can only attempt to do justice to in the analysis and discussion to follow. I no longer felt the need to ask questions. Rather, I let my informants speak about their experiences and talk about PCMIC in their own way. I probed for elaboration and detail, asked follow-up questions, and made comments when appropriate. But my neatly organized interview guide was quickly abandoned and I ended up with audio recordings ranging from two and one half hours long to four hours long, filled with rich stories and conversation. Rather than conducting semi-structured interviews, I realized I had in fact recorded oral histories. These histories were first-hand accounts of what it meant to live in Institute as 
well as provided insight to the history and development of PCMIC and their experiences as activists and environmental advocates.

Oral histories are a significant tool for those attempting to bring marginalized voices to the forefront. Similarly, oral histories have become a way of "recovering the experience of those whose lives were in danger of being hidden from history" (Jackson and Russell, 2010). The voices of those suffering from environmental injustice are often left behind - even by researchers who aim to create transparency between noxious facilities and the communities within which they are located. Oral histories provide scholars with the ability to practice situated knowledge, defined by Haraway (1988) as an attempt to make critical and objective claims but viewing the source of knowledge as equally important in the production of those claims. Situated knowledge was born out of the critique of positivist science, which often views informants and sources of information as objects of study rather than entities of agency (Haraway, 1988).

Oral histories can be defined as "an informal question and answer format with a person who has first-hand knowledge of a subject of interest" (George and Stratford 2010, p. 140). They have often been described as a way of creating a people's history; a method of bringing insight to the non-hegemonic discourses that may dominate a particular narrative using the voices of those who have been hidden from history (Portelli, 1981; Riley and Harvey, 2007). These undocumented stories complicate the accepted narrative of popular issues and debates. Of particular interest for this project is how the stories and experiences of the activists of PCMIC alter our understanding and perceptions of the Bhopal disaster and environmental justice struggles in its entirety. 
Many scholars use oral histories in order to contextualize place, space, landscapes, environments, and scale. In their discussion of how oral histories inform the geographies of elders, Andrews et al discuss the concept of emplacement. Emplacement is the idea that "places serve as a crucial material and symbolic source for biographical development and, as such, make an essential contribution to the construction of personal identity" (Andrews et al, 2006, p. 154). In turn, oral histories reveal how concepts of place, home, and their historical contexts inform the identities of informants. This perhaps explains the large emphasis on the historical development of Institute, WV as revealed by several of my informants (see analysis and discussion for details).

The concepts of place, space, scale, and how they relate to identity are core to the discipline of geography. Despite their prevalence and heightened importance in oral histories because of how they inform the recollection of place, oral historians do not engage with these concepts - leaving much to be developed by geographers in terms of oral histories as a methodological approach (Andrews et al, 2006). In fact Andrews et al (2006) put forth three main critiques of the ways in which the concept of place is (or is not) addressed in oral history projects. Currently, place is engaged with in a very superficial matter - often referred to in passing as the location or setting of the project; the creation of place and place-identity are not addressed as products of differing scalar phenomena; and lastly, despite detailed accounts provided by informants, there is little attention paid to the every-day lived experiences of the informants (Andrews et al, 2006). Rich data provided by informants in regards to how place and identity are co-created, and how the everyday lives and experiences of individuals are linked to place, could 
potentially yield powerful contributions to discussions of landscape analysis and the social construction of place - led by geographers.

Although potentially empowering, there are many caveats to using oral histories as my core methodology. First, it is questionable whether or not an individual's memory of an event can be trusted as "factual". Second, oral histories reflect the personal biases of the informant. Finally, oral histories often become an object of study rather than a methodological approach to research (Andrews et al, 2006; Jackson and Russell, 2010; Portelli, 1981; Riley and Harvey, 2007). The selective nature of memory and nostalgia affect the reliability of information shared by interviewees (Riley and Harvey, 2007). It is argued that the quality of data deteriorates as time passes due to the fact that memory is shaped by the events and feelings an informant chooses to hold onto over time. Subsequently it is important to supplement oral histories with archival research in order to develop a complete contextualized account of an event, place, or experience.

In addition to recording six oral histories, I accessed several online collections of the West Virginia state archives. I also used articles from the Charleston Gazette, the West Virginia capital's newspaper, to create an even more in-depth contextualization of my data. Archival research is significant for the discipline of geography for reasons beyond simply creating a geographic understanding of the past (Roche, 2010). Archival and historical research methods allow geographers to re-evaluate current geographic and political concepts so that we may develop a better understanding of present-day phenomenon (Roche, 2010). Arguably, these current geographic and political concepts can be understood as current-day recorded memories. If we are able to step back and 
examine recorded memories and histories as parts of a complex story, then we are able to see the value in supplementing those histories and stories with archival data.

Despite the above-mentioned critiques of oral histories and their reliability, many scholars argue that oral histories are no more susceptible to bias than any other method of qualitative research. Even archival research is shaped by bias as the researcher and the authors of historical materials choose which documents to include in their studies, whose perspective from which a document will be read, and what information will be included in that write up. Additionally, the process of transcribing any form of spoken word (be it structured or semi-structured interviews) "betrays the form by turning eloquent oral performances into unreadable texts. There is no such thing as a neutral transcript: each comma is an act of interpretation [...]" (Portelli, 2011, p. 10). Even the initial selection of our research topic is the result of an interpretation of an event or phenomenon (MacKian, 2010). Therefore it can be argued that oral histories are no more or less biased than any other qualitative method (Riley and Harvey, 2007).

Furthermore, it is not typically the goal of a qualitative researcher to make truth claims based on data collected via oral histories. As discussed above, oral histories emerged in an attempt to critique positivist approaches to science and instead use situated knowledge in order to problematize the hegemonic narrative about an event, landscape, etc. Because the human brain does have a tendency to morph memories in order to reflect an idealistic portrayal of an event or phenomenon, oral histories "are not regarded straightforwardly as representations of the past [...] but as a means of examining how individual narratives are socially and culturally constituted as part of an on-going explanatory and relational process" (Jackson and Russell, 2010, p. 175). Personal 
histories and memories are shaped by former and current political, economic, and environmental contexts in which they are not only created, but also shared. Because they are so reliant on these contexts, oral histories can be understood as a dialogue between an informant and the broader context (often place) during which those memories were formed and reproduced.

In order to build a more rigorous historical account of PCMIC, and contextualize the data collected from the oral histories, I also accessed the West Virginia State Archives online database. The archives were particularly useful when compiling a history of Institute, WV and the chemical industry in West Virginia. Some of the information I retrieved through the archives was from sources like state-published history journals and historical non-fiction texts. Additionally, I drew information from the 1991 documentary film Chemical Valley. Chemical Valley highlights the struggles of those living near the Institute Industrial Park during the aftermath of the Bhopal disaster. In fact, many of my informants are seen giving interviews throughout the film.

\subsection{Analysis}

For this project I engage with the scale of the individual in an attempt to understand PCMIC according to the every day experiences of my informants. Both Bullard and Pulido discuss activist perceptions and definitions of environmental hazard as being the root of grassroots efforts.

The decision to take direct action or to tolerate a stressor often depends on how individuals perceive their ability to do something about or have an impact on the 
stressful situations. Personal efficacy, therefore, is seen as a factor that affects environmental and political activism. (Bullard, 1990, p. 2)

It is the experiences and perceptions of risk at the scale of the individual that create demand and lead to the formation of activists groups. In order to understand the group People Concerned About MIC, I must acknowledge and expand upon how the differing experiences of my informants create the various dynamics present within the group. In order to do so, I conducted a framework analysis of the data produced in the oral histories.

A framework is the way in which an individual (or group) represents and articulates grievances and concerns and can also "be viewed as a scheme of interpretations that guides the way in which ideological meanings and beliefs are packaged by movement activists [...]" (Taylor, 2000, p. 511). In order to understand PCMIC according to the perspectives of individual activists, I need to first assess what drove individuals to create People Concerned. This rests on analyzing how each activist defines the struggle in Institute and frames that struggle in an attempt to raise awareness. Frameworks utilized by groups in order to attract new activists or supporters are collective-action frames (Martin, 2003; Taylor, 2000; Snow and Benford, 1988). Snow and Benford (1988) argue that collective-action frames consist of three framing components: diagnostic, prognostic, and motivational. The ability of a movement to successfully recruit activists may be determined by how well each of these components is developed and clearly articulated (Snow and Benford, 1988). These three frameworks, in addition to a fourth framework - scale - informed my data analysis. 
Through framework analysis, several key themes became prevalent throughout the data collected: Race, class, and community health. Community health is a term used to describe not only the health and quality of life of the individual, but how the community itself thrives within the climate of political and environmental contention. The series of complex relationships that define the Institute community are inextricably linked to the health of the individual, as influenced by the plant, but also how different people interpret the plant as an economic life source of the community. Various informants view the plant differently- some fundamentally opposed to its existence while others understand the reality of job production and cannot argue with the revenues generated for black community members. However, the racialized history of hiring practices at the plant makes it difficult to "side" with Carbide for even that reason.

Although not explicitly discussed by participants, these core themes reflect the underlying motivations that drive individuals to become motivated to join People Concerned. In the section to follow, I have outlined and organized my data according to the four main frameworks used for data analysis. However, it is important to note that the key themes are what drive the discussion section of my project and inform how this research contributes to a larger literature on locational conflict and environmental justice.

\subsection{Diagnostic Frameworks}

Diagnostic framing refers to identifying main concerns and attributing blame or causality to a specific party. Examples of data collected from informant discussions that fit into this framework include: the core reasons why People Concerned was created, personal experiences that led a member became involved, and who an individual holds responsible for those experiences and concerns. Data is organized into two main groups: 
defining the problem and attributing blame. Participants provided varying insights as to why People Concerned materialized. Within the first group I have identified six general themes that surfaced when respondents alluded to the issues that inspired the creation of PCMIC. These themes are: living downwind of a chemical plant; chemical emissions, being exposed to several chemicals simultaneously; the illnesses and deaths of loved ones; the racial composition of Institute; their suffering as a direct result of their low socio-economic status.

\section{1 (a) The problem:}

Once informants started to describe the formation of People Concerned it became clear that the heart of PCMIC was rooted in living downwind of a chemical plant (as demonstrated by the title of PCMIC's newsletter, The Downwind News). Several informants referenced the geographic juxtaposition of the plant and the community explicitly. Willy, one of the original founders of PCMIC, explains the difficulty of escaping harsh chemical emissions that leave the plant when they float directly onto the community,

Everything that came from Carbide at that time $[\ldots]$ all of the particles and particulates, whatever you wanna call it, came from the West to the East.... (Sobey, Personal Interview, 2014)

Willy goes on to explain that his father taught at West Virginia State College in a building that faced the chemical plant. Because the building lacked central air and cooling, professors taught with the windows open. As a result, Participant Four's father was forced to breathe in chemical emissions daily. 
Similarly, majority of the homes in Institute use window air conditioning units or rely on open windows for air circulation because the homes are older and many are not able to afford central cooling. Diana explains the important role of central air (or lack thereof) in her own story of exposure:

When I was 14 they [Institute Plant] had a chlorine leak that literally completely covered the town, you could not see anything in front of your face. I was forced, because I was the tallest person in the household- which was all women - I was forced to go out into that to roll in the windows. [...] You could push them open with your hand, but you had to go outside to push them closed. I literally spent 45 minutes closing all the windows and climbing on the roof and getting the second floor windows. (Sobey, Personal Interview, 2014)

Diana reflects on the window treatments in her home, which required her to manually push them closed from the outside because they no longer worked properly. In order for her family to properly shelter-in-place, she had to go outside and enter into the toxic cloud that she believes is the cause of her current health complications. It is critical to note, however, that not all exposures to chemicals have been due to large-scale plant catastrophes or leaks. On the contrary, much of the emissions take place during routine, government allotted, releases.

As indicated by informants above, chemical emissions, as experienced due to living next-door to a chemical plant, is among the core problems that led to the formation of People Concerned. However chemical emissions are only a source of conflict because they impact individuals negatively via exposure. Exposure occurs when an individual comes into direct contact with the emissions released from the plant (regardless of 
whether or not they were routine emissions or a plant mishap). It follows that many believe chemical emissions result in the untimely deaths and severe illnesses of loved ones and fellow community members.

Because emissions played a critical role in motivating community members to join People Concerned, the ability to detect odors became an increasingly important and controversial component of the fight against the plant. Whenever individuals smelled foul odors or chemical-like smells they would call the plant and file a formal complaint. Then, they would call fellow community members to see if they also smelled the questionable aromas, and file a complaint. Eventually, so many complaints were filed in regards to odors that the Institute Plant would send "smellers" into the community to measure the severity of the odor and determine which chemical was responsible for the aromatic assault.

Originally, smellers were white men who lived outside of Institute but worked for Union Carbide. As expected, designated smellers could very rarely confirm that the odors reported by community members were existent. Often smellers would refute claims by stating they simply didn't smell anything. Participant Four reflects on a time when a smeller could not verify a reported smell:

Hilary [his daughter] grabbed me by my pant leg and pulled it and I looked down at her and she said, 'daddy? Did he say he didn't smell anything?' I said, 'he sure did" and she said, 'something's wrong with his nostrils'. I'll never forget that as long as I live. (Sobey, Personal Interview, 2014)

Eventually the chemical companies began to send workers with which the community could better identify. It was when Participant Four's neighbor showed up, as an official 
smeller, to investigate a smell that Wally realized a "smeller" was a position created to silence community members without any specialized training or equipment.

They would send a guy that I had never seen or heard of before - usually a white guy. And I'm taking for granted that he has a background in sniffin' [...] I don't ask him what his credentials are or anything [...]. And then one day they sent a guy up here, Paul: here's a guy that I know everything about him - and he's probably never had a chemistry class in his entire life and I say, 'I'm awe struck they sent you, what's your background in chemistry? (Sobey, Personal Interview, 2014)

The testimonies of my informants reveal the harmful health affects of these odors and chemical emissions, in turn, becoming a motivating factor of People Concerned. Scarlet explains that she became interested in joining PCMIC because:

My husband had died in 1986 [...] we celebrated our seventh anniversary, we didn't even get to celebrate our eighth anniversary [...] and we didn't really have any time together before he came down with cancer and died. And here my children are, we're going through emissions, and we're breaking out. I've got spots on my skin where you've had bumps and then they would burst and turn to spots - everybody down here has something like that. And I resented it. (Sobey, Personal Interview, 2014)

Informants emphasize that it is not just exposure to chemical emissions that they take issue with, but the fact that community members are breathing in several undisclosed chemicals simultaneously. Patricia, a former member of the West Virginia Department of Environmental Protection, explains that, 
It's not like when I breathe I can breathe sodium today and butadiene tomorrow or acetone the next day. When I'm breathing, I'm breathing all of them in at one time $[\ldots]$ (Sobey, Personal Interview, 2014)

Similarly, Diana adds:

They're making more than one product at that plant and then of course they have an allotment for each of those different chemicals, right? Mkay, so then you times that by $[\ldots]$ how many years people have lived here... and all that's running through our tissue and blood system. (Sobey, Personal Interview, 2014)

In fact, chemicals tested for their impact on human health have only been tested as isolated factors. The unfortunate reality is that the plant emanates several chemicals simultaneously due to the various products being manufactured and companies operating within the facility. Therefore, as demonstrated by the above quotes, many believe the differing chemicals released from the plant react to one another - having a different effect on the human body and environment than when exposed to a single chemical.

As informants continue their stories, they begin to speculate as to why their community was chosen to have a neighbor that releases chemical emissions and stored the deadly Methyl Isocyanate. For many, race is a large contributing factor:

Well I knew why they brought it in: because it was a black college in a black community so therefore this black college in this black community was expendable. [...] we were non-people. I knew that's why the MIC was brought in and placed here and not in South Charleston. (Sobey, Personal Interview, 2014) 
The above quote is a sentiment echoed throughout the oral histories provided by all of my informants. Additionally, in a documentary film about People Concerned About MIC created in 1991, several community members not affiliated with PCMIC are recorded making similar assertions. Many contemplate whether or not the plant would have been placed in Institute if the surrounding communities been white and more affluent or if the plant would function as recklessly.

In his analysis of activism in Institute, Bullard asks survey respondents to identify and rank the core issues facing the community. After compiling the responses of approximately 101 surveys, Bullard determines that air pollution and the threat of toxic leaks are the top concerns in Institute. In fact, in his overall summary of the book Dumping in Dixie, Bullard provides a brief description of each of his five case studies and identifies one issue that embodies the core of each movement; Bullard describes Institute as being a case study centered on "chemical emissions". Bullard's description of activism in Institute, in accordance with self-identified concerns, aligns with the results and themes of the oral histories collected for this project.

Through the analysis of my data, I have found that members of People Concerned were most interested in remediating the effects of chemical emissions and air pollution exacerbated by their geographic proximity to a potentially deadly chemical plant. This is especially evident when participants describe the everyday experience of living downwind of the Institute Plant. Emphasis on odor and repeated mention of the synergistic ingestion of chemicals leads me to believe that incidental exposure as a result of breathing government-allotted emissions is perhaps of more concern than the looming threat of a large-scale leak. 
Additionally, in an open-ended survey question, 88.6 percent of respondents cited race as the number one reason they believed their community was singled out by an industry (Bullard, 1990). Institute had the highest percentage of respondents who felt race was the most important factor in the decision-making process of industry. Once again, Bullard's understanding of activism in Institute as being driven by race echoes the findings of this project. Informants very clearly established the importance of race in the development of their communities and referenced race (in conjunction with class) as the reason Carbide unfairly targeted their home as the new location for the plant.

Through my data I am able to uncover that there are varying ways activists define and interpret the goals and purpose of the small grassroots group, People Concerned. Bullard reminds us "Environmental justice activists have not limited their focus to toxics or racism. Their movement is inclusive, cutting across race, ethnicity, class, region, and political affiliation” (Bullard 1990, p. 123). Likewise, Pulido encourages an intersectional approach to these injustices (which are commonly examined in an isolated fashion) similar to how activists desire chemical emissions be studied in Institute. My data, bolstered by the findings of Bullard, illustrates that not only is environmental justice complex, but so too (and most importantly for the purposes of this project), are the ways in which Institute activists understand and frame their injustices.

\section{1 (b) Who to blame}

The second component of the diagnostic framework identifies the parties to blame for the above -mentioned causes and concerns recognized by group members. Generally speaking, informants identified two main culprits: the federal government and "corporate America", more specifically chemical companies such as Union Carbide. For many who 
have lived in the community for several decades, the Institute Plant is remembered as belonging to Union Carbide despite having changed ownership several times,

I'll always call it Carbide, it's changed names a hundred times but I still call it

Carbide [...]. (Sobey, Personal Interview, 2014)

Union Carbide's reputation was quickly and permanently tainted because of their role in the Bhopal disaster.

However Diana expresses discontent with the chemical industry, which existed prior to the catastrophe in India. Alluding to the initial decision to place the plant in Institute, she suggests that injustice begins when corporations pursue the bottom line at the expense of Others:

Corporate America has used us as lab rats ever since they put that plant in this area. They had no consideration of what life would be like being forced to inhale or be covered, or our environment in which we live. We were nothing. We are in the shadow lands of America [...]. (Sobey, Personal Interview, 2014)

Ultimately the decision to locate a potentially deadly chemical plant in Institute, WV can be traced to a desire to exploit a specific population considered in need of modernity, but that is also worth the risk of any inadvertent consequences. Diana references how individuals are forced to inhale and be covered by emissions (identified above as a core concern of the group) at the hands of "corporate America".

The federal government, in accordance with neoliberal marketing strategies, often aligns their interests with those of the chemical industry. An essential feature of this alliance is self-regulation, 
They basically get to monitor themselves, which I think is one of the biggest slights the federal government has laid upon our town, is that they're allowing a industry to self regulate- a deadly chemical company. (Sobey, Personal Interview, 2014)

Unfortunately, self-regulation is common among industries that often have a heavyhanded influence on local, regional, state, and national economies. Additionally, these industries typically have large and lasting impacts on the physical environment; McNeil (2012) provides an in-depth discussion of how self-regulation of the coal industry has resulted in increased pollution and incidents resulting in catastrophe. Implications for chemical industry self-regulation include relying on the industry to: provide fair and accurate water and air pollution testing, maintain safety equipment and evacuation preparedness, report any incident which results in the unlawful emission of chemicals, conduct health studies and test the impacts of all chemicals in the event of exposure. However, because the federal government no longer allocates monies to companies in order to enforce these standards, the company must pay for them. Thus, companies often cut corners in order to achieve maximum profit and maintain (often) minimal safety standards.

Blame for the plight of Institute, according to my informants, is twofold: the federal government is to blame for allowing the chemical industry to self-regulate and the industry itself for inadequately self-regulating. The government, however, has set a maximum threshold for the amount of emissions released per month, which is specific to differing chemicals. Companies are thus responsible for reporting all of the different 
chemicals being released into the air. One participant refers to the effects of selfregulation:

They're [Bayer CropScience] using chemicals down there that they have no idea what it's gonna do to them and probably those students down there [at West Virginia State University] in 15 years will come down with some [indiscernible] kind of cancer and it'll be blamed on cigarette smoking. (Sobey, Personal Interview, 2014)

Companies are able to dismiss illnesses reported by community members because their corporate-funded testing may show that there is no relationship between the chemicals being produced by BayerCropscience and the ailments being described. This phenomenon is common when grassroots groups begin to challenge the status quo of influential industries. Unfortunately, due to the infinite availability of resources, companies can often explain away health-related grievances by engaging with a specific rhetoric of Science that delegitimizes the efforts of community members. As referenced in the quote above, the chemical companies are able to successfully deflect any claims that BayerCropscience has negatively impacted one's health by shifting the blame to cigarette smoking.

It is important to emphasize, however, that no single party is to blame, "the main thing is that it's a compound thing. The federal government says that you can release- so you get these monthly allotments [...]" (Sobey, Personal Interview, 2014). The culmination of government regulation (or lack thereof) and an economic climate that favors the success of industry combines in order to create the conditions of opportunity that have lead to the creation of People Concerned About MIC. 
Bullard does not necessarily explore whom activists define as the source of their issues. However, identifying the chemical companies (or corporate America) and the federal government as main actors does reflect a vast majority of current environmental

justice literature. For example, the neoliberal economics and Multi National Corporations (MNCs) models and their impacts on the safety of communities and environment has been explored in detail by scholars such as Fortun (2001), Gunewardena \& Schuller (2008), McNeil (2011), and many others. The ability for capitalism to seek out spaces in which to create crisis is inevitable and founded on systemic prejudice such as racism and classism. As a result, members of People Concerned clearly identify a system that values profit above the lives of poor black communities as the source of conflict.

\subsection{Prognostic Frameworks}

Prognostic frames identify solutions and strategies to address the concerns and culprits listed above. Consequently these solutions vary according to how individuals define the issues most pertinent to People Concerned. Thus the material actions taken by the group are a direct result of how individuals frame MIC production and life in Institute. There are approximately four principal solutions as revealed through the oral histories as well as archival research. The proposed solutions to combatting chemical emissions and remediating livelihood impacts include: establishing more accurate alert systems and efficient evacuation routes; conducting studies on the synergistic effects of air pollution on the bodies of residents; raising awareness of the uneven distribution of environmental degradation; and pressuring the local and federal governments to enforce safety. At the core of the problems identified in the diagnostic framework are chemical 
emissions. Consequently, the majority of the solutions pursued by the group concern monitoring and regulating air quality.

Although there are four core solutions, the strategies to achieve these four goals vary immensely. These differing strategies, which range from phone trees to hosting Bhopal disaster survivors, directly reflect the economic and cultural context as well as group leadership and membership dynamics. When the group first formalized in 1985 , issues of immediate concern were rooted in identifying plant odors, as described above in some detail. When community members smelled questionable fumes they would first call the plant and file a formal complaint. In fact, Wally kept a log of every time he smelled a foul odor on the bindings of an old phonebook that sat beside his telephone. Following the date of each time he smelled something, Wally would call the Institute Plant and file a formalized complaint. He recorded the time and date of the conversation, and the name of the person he spoke with - if available. Afterwards, they would call one another and engage an unofficial phone tree. In the beginning stages of the group, phone trees served as the primary means of communication between group and community members until the PCMIC began meeting regularly. Conversation between Institute residents was relatively sparse in the early years of People Concerned. However, once the group began circulating informational pamphlets and hosting meetings, conversation surrounding plant-based issues began to flourish.

The propinquity of the plant and the late events in Bhopal drew on the fears of Institute citizens. As a result, the early aim of PCMIC was to achieve better emergency and evacuation preparedness. Many citizens were (and continue to be) unhappy with shelter-in-place techniques, as highlighted above, due to the fear and trauma associated 
with the practice. In order to enact change, the founding members of People Concerned first began writing small op-ed pieces and attending community planning meetings - at which plant officials would be present. Members used these meetings as a platform to formally express grievances directly to plant representatives, in an attempt to create transparency among the industry. Frustrated by the (lack of response) by the plant, People Concerned began to host group meetings every few weeks. No plant representatives were invited to attend.

Several years later, leadership shifted and the group became more concerned with the health impacts of living next door to the plant. More specifically, there was an outcry for health studies that examined the synergistic effects of ingesting several chemicals at once. In an attempt to create clout within the community, People Concerned began circulating even more public information and increased their presence within local media. People Concerned began to publish a newsletter every quarter, The Downwind News. One copy of the Downwind News, provided by an informant, included the results and discussion of a health survey PCMIC conducted in 1988.

Patricia, one of the co-chairs of People Concerned, was very dedicated to approaching the injustice in Institute from the perspective of "logic". When asked why she became involved with PCMIC, Patricia responded,

When they made the decision to do certain stupid stuff down there, that I felt was illogical, [I wondered] what logic they used to make these decisions [...] So I went to school to figure out what logic they used [...]. (Sobey, Personal Interview, 2014) 
One of Patricia's greatest accomplishments was spear-heading a community health survey that assessed self-reported illness and gauged community concerns for air pollution and quality as it pertains to the plant. The purpose of the study was not, however, to determine a relationship between the plant and community health.

The survey, The Institute, Pinewood Park, West Dunbar Area Health Study

(IWPD), was commissioned by PCMIC and used the same techniques and approaches applied by the National Health Interview Survey (NHIS) because they were widely accepted as being rigorous. The IPWD Area Health Survey compared the incident of selfreported illness between the NHIS study and the results of their own survey. The survey found that African Americans living in these three areas were at increased risk of twelve different health conditions, including Hay Fever, itching skin, hearing impairment, bronchitis, and others. The presence of these illnesses in the African American populations of IWPD was considerably larger than those numbers reported by the NHIS 1986 study.

However, despite Patricia's efforts to use logic and citizen science to combat the chemical plant, the study was rejected by nearby chemical companies and the group's spirit suffered at the survey's lack of success. As a result, many of PCMIC's members sought alternative strategies and became disinterested in the group. Some of the different community groups that materialized when PCMIC was created were more formally organized and received monies from the plant in order to complete community improvement projects (installing stop lights, repairing potholes, paving streets, etc.). These groups also regularly had plant representatives in attendance at their meetings and 
maintained open communication with plant managers. Additionally, in 1991 Patricia became severely ill and had to step down from her position as co-chairman of the group.

During this prolonged lull of group activity, members of People Concerned reverted to conducting un-organized individual acts of opposition. Informants reported that they continued to call and file formal complaints whenever they would smell harsh odors, and several individual lawsuits were filed against the plant. These lawsuits were centered on health complications believed to be caused by plant emissions, and were almost always thrown out of court. A key strategy during this period included sharing testimonials. Informants would share their exposure stories and fight to keep the everyday lives of Institute citizens on the radars of local officials whenever they could.

Group members have been able to highlight the struggle of the everyday and raise awareness by engaging outsiders with immersive geographies. One immersive way individuals share their testimonies is through the toxic tour. Whenever possible, People Concerned drives individuals through the Institute community, visiting important sites of contamination, leaks, and other hazardous events. The tour drives past the Institute Industrial Plant, across the river to St. Albans, and visits sites where the 2008 explosion was most visible and the smell was strongest. In October, 2013 I was able to go on a toxic tour with Melanie. She drove me through West Virginia State University campus, showing me where the dilapidated and abandoned rehab center stood, the sporting fields, a children's day care center, and the various "shelter in place" accommodations located throughout the campus (See Image 2).

In fact, the room in which two of my interviews took place on WVSU campus was clearly identified with a bright yellow placard as being a "shelter in place" suitable 
location. Without recognizing it, I had been submersed within the everyday risk of my informants. Likewise, several weeks before I conducted my fieldwork, there was a largescale chemical leak that contaminated the water of 300,000 WV citizens. Several of my interviews took place in the homes of my participants, but all took place in the nodrinking zone of water contamination. Participants offered me coffee made from outsourced bottled water in an attempt to show their hospitality. I was warned not to wash my hands after using the bathroom and was handed a small bottle of anti-bacterial gel on my way to the restroom. Additionally, I met one informant at a restaurant for lunch and was surprised (but also relieved) to see a newly invented "water tax" applied to my bill in order to account for the expense of cooking with bottled water.

Since the group's creation in 1985, People Concerned has also hosted several survivors of the Bhopal disaster. In an attempt to raise awareness, People Concerned has organized several panel discussions with Bhopal survivors and has also served on countless panels at local, national, and international conferences. In fact, the current president of People Concerned recently traveled to New York City and Boulder, Colorado in order to share the story of Institute at the 2014 International Campaign for Justice in Bhopal annual conference.

In addition to traveling across the country to share the story of Institute the current president of People Concerned, Melanie, directed the 2011 lawsuit (discussed above). Despite the efforts of those who had filed personal complains throughout the years, the 13-person suit was finally able to capture the media attention and community support needed in order to halt BayerCrop Science. This lawsuit was the first to be filed as a collective effort of People Concerned and marked the end of the group's mostly dormant 
period after Patricia stepped down from office. Melanie explained that PCMIC "tried to push a civil rights approach" with the lawsuit in order to accentuate the racial underpinning of the struggles in Institute. However the group experienced difficulty finding a lawyer in the Charleston, WV area that did not have a conflict of interest and would also support the case with such a direct racial position. Many of the lawyers and law firms in the surrounding areas had ties with Bayer CropScience or other chemical companies throughout the valley; this made it increasingly difficult to express the racial complexities of PCMIC. Eventually the National Resource Defense Council became involved with the lawsuit and the group settled on using an environmental justice approach. Although disappointed in their inability to file a civil rights lawsuit, Melanie expressed that the group was pleased with the outcome of their efforts and found that 'environmental justice' accurately captured the injustices suffered by Institute community members. Ultimately Melanie believes that environmental justice and environmental racism are the best lenses for examining chemical catastrophes and social justice in Institute.

Although the group has seen what many consider great success in recent years, the dynamics of the group have changed dramatically. Melanie explained that despite successfully removing MIC from Institute, group tactics are far less community outreach oriented than before. Currently, Melanie makes more executive decisions about group activities and how to manage funds. As a $501 \mathrm{C}-4$, the group may receive funds from anonymous donors through their website and also has a designated office space in downtown Charleston. In large part, Melanie's actions have also been dedicated to raising resources for the group so that she may travel to Washington D.C. for lobbying activities and hearings, as well as conferences. 
Previous to Melanie's time in office, People Concerned was more horizontally organized. As explained above, People Concerned held regular community meetings and communication between one another was far more prevalent. Today the group does not hold meetings, nor do they enact a phone tree or even have an email listserv. This shift in leadership style has been commented upon by nearly all of my informants as both positive and negative. In some regards, informants don't feel that Melanie represents the community of Institute because she is from across the river. However, informants recognize the great level of success she has had in the past few years and admire her ability to create progress. In large part, her ability to be successful is linked to her age (young and resilient) and her whiteness. Throughout the group's history, there have been two white leaders. In fact, the founding figurehead of the group was a white man. One informant explicitly states that it was never a strategy, per say, to elect white leading officers. But that having white leadership has granted the group access and opportunities that may not have been available to them if their leader was an African American. It is perhaps important to highlight the disconnect that exists between the diagnostic and prognostic frameworks in regard to race. Despite the fact that racial inequality was among the most important problems identified in the diagnostic framework, there is little mention of race and racial inequality in the prognostic framework.

Relatively none of the solutions or strategies proposed by People Concerned are primarily concerned with racial inequality. Melanie's attempt to frame the 2011 lawsuit as a Civil Right's issue is perhaps the most poignant example of how People Concerned wishes to use race in their strategic approach to justice. However the February 2014 Water Rally I attended, which was in part organized by People Concerned and several 
other groups, focused on racial injustice as the leading cause of neglect following the water contamination. In fact, the NAACP (the National Association for the Advancement of Colored People) was present and helped organize a large portion of the rally. A letter to president Obama and a petition requesting the presence of the EPA in Charleston for an official "hearing session" was passed through the church and attendees were asked to sign. On the letter, there was a space where individuals could indicate a group or organization they were representing. After signing the petition myself, I looked up at the letter and saw that one man had written "the Black Man" within the organization/group space.

Although it is clear that my informants understand and define their injustices as being racial, People Concerned does little to address those perceptions when addressing the issues highlighted in the diagnostic framework. Above I have provided some speculation as to why this may be; these different ways of racially framing injustice will be discussed further in the conclusion of this paper. As with many grassroots groups, strategies and goals are in a constant state of flux and reflect the values of current leadership. Changes in leadership experienced by People Concerned have provided the group with a layered and complex approach to fighting the manufacturing of MIC in their community and the decisions leading to the sighting of the Institute Industrial Park more broadly. These differing strategies, from phone trees to citizen science to multi-party lawsuits, have had varying levels of success and help define the group today.

\subsection{Motivational and Scalar frameworks (the power of place)}

For the purposes of this project, I have combined my discussion of motivational and scalar frameworks because I find that the power and presence of place throughout my 
data has entangled these two frameworks. Although both frameworks are useful for determining how People Concerned motivated activists, motivational frames provide the broader context within which scale frames are nested. The following section will briefly review these two frameworks and proceed with an analysis of how place has shaped the development of People Concerned.

Motivational frameworks highlight any rhetorical strategies or materials used to motivate new activists and are best described as a "call to arms" (Kurtz, 2003; Martin, 2003; Snow and Benford, 1988). These frameworks refer to how grassroots groups articulate their grievances specifically for the purpose of attracting new participants. Protest materials such as pamphlets, newsletters, picket signs, etc. are often key indicators as to how a group is trying to appeal to community members. These techniques often draw on emotions in an attempt to interest activists. An example is Image 1, produced and circulated in a 1988 copy of the Downwind News (a newsletter circulated by PCMIC every quarter during the late 1980s). The imagery of a woman holding a small child perhaps invokes within readers a concern for family safety and draws upon the identity of motherhood. Motherhood, as discussed by Bell (2013) is often cited as the primary motivating factor for working-class women activists, especially in Appalachian communities and communities of color.

Similarly, scale frames appeal to sentiments linked to home and community by using place as the primary signifier. Because of the place-based nature of oral histories, the scale frame provides me with the analytical tools necessary for more accurately interpreting what lies at the core of my data: the significance of the place, Institute, WV. As described above, motivational rhetoric uses ethos in order to appeal to community 
members. More specifically, scale frames draw on emotional attachment to place and romanticize about the ideal place - one devoid of the particular conflict in question - in order to motivate activists (Martin, 2003). For example, a grassroots group dedicated to preserving air quality would perhaps describe children safely playing outside, breathing in fresh mountain air. Rather than, for example, discussing the inability for children to play outside due to the uncleanliness or smogginess of the air.

Arguably, much of the testimonies provided throughout this project allude to what composes an ideal Institute through the eyes of different informants. However, it is the tone and emotion evident in a response that leads me to classify some data as belonging to the "motivational framework" as opposed to the diagnostic or prognostic frameworks. For example, in response to my asking why Diana became involved with People Concerned, she responded with:

Your family might reap some financial gain right now, but your grandchildren aren't and your great grandchildren aren't [...] I don't care if you save one person by changing the laws to better the world, then that one person has the tendency to live long enough to reproduce, and you have a life-giving substance of a place. (Sobey, Personal Interview, 2014)

In the above quote Diana describes an Institute where an individual is better able to safely reproduce and give life to future generations. In fact, according to many informants, the ability to sustain life in the valley (in all facets) starts with the wellbeing of the individual. Diana continues on to say,

Whatever you're giving me, and passing along to me, it's gonna filter over to you. And that's the reason we fight. (Sobey, Personal Interview, 2014) 
Consequently, the economic and environmental status of the Institute community suffers alongside the health of the individual. Thus there exists a dialectical relationship between place and the individual, ultimately impacting the overall health of the community. Community health is the lens I am applying to my data in order to draw connections between the different framework analyses conducted, and ultimately answer my research questions.

There is much scholarship dedicated to understanding the complexities that define a community. However in an attempt to circumvent this large dialogue, I refer to Gregory et.al's summary of these discussions in the Dictionary of Human Geography. Broadly, 'community' is a term used to signify a conglomerate of people who live within close proximity to one another (sometimes a neighborhood), often share similar values, and who participate in similar modes of production and consumption. Community health, for the purposes of this project, refers to protecting the idealized place of Institute, as demonstrated by the differing perspectives of informants as well as the actions of People Concerned.

According to my data, community health is achieved in two ways: protecting the biological wellbeing of the individual and preserving the cultural and historical significance of Institute. The relationship my informants create between personal health and community has been presented above, although briefly. However I'd like to focus the remainder of this place and motivational frameworks discussion on the importance of cultural and historical preservation.

Although there exist many examples of how place has shaped the perspectives of my informants, as well as the dynamics of People Concerned, the most poignant example 
is the unprompted telling of the history of Institute. Two of my informants found the history of Institute so critical that they spent almost one quarter of their interview time explaining the origins of the unincorporated township to me on their own avowal. The history of Institute as provided in sections prior is incomplete and only reviews the presence of the chemical industry in Institute. Below is a more comprehensive history of Institute, as informed by several participants and bolstered with West Virginia State archival materials. I include the revised history within this section of my project because I believe the original story of Institute provides a framework for understanding how PCMIC activists experience injustice and helps contextualize how race has informed the development of Institute, WV.

\section{3 (a) The racialized place of Institute, $W V$}

The settlement of Institute, West Virginia began with what many depict as a grand love story between a property owner and his slave (Haught, 1971). Samuel Cabell, a wealthy landowner from Virginia, moved to present-day Institute in roughly 1853 with several slaves he acquired in Virginia. He fell in love and married one of his slaves, Mary Barnes, and fathered several children with her. It is rumored that his white neighbors unsettled by his integrated lifestyle- murdered Sam. Court documents reveal that Sam left all of his wealth and land to Mary and their children in addition to demanding that his family become freed people at his passing. The land purchased in 1891 in order to establish West Virginia Colored Institute (West Virginia State University, today) belonged to Elijah Hurt - the son of Sam and Mary. It is rumored that the land was actually bequeathed to their daughter, but because African American women could not own property, Elijah's name was officially designated as the heir on the will. Soon 
Institute became a community dedicated to the safety and equality of blacks, and the home of the first learning institution in the state dedicated to creating opportunities for African Americans.

West Virginia Colored Institution, which prompted the name of the township, was home to the country's first Army Specialized Training Program (ASTP) and ROTC for blacks in the country (Morgan and Cork, 1894; Keefer, 1994). Roughly the same year ASTP was established at WV Colored Institute, the Civilian Pilot Training Program (CPTP) at Wertz Field was founded. At the time CPTP was enacted, there were only twenty black licensed pilots in the entire country. Training at Wertz Field became a prestigious honor; in fact, two of the pilots trained at Wertz Field went on to be Tuskegee airmen. Additionally, the first black woman pilot to serve the West Virginia Civil Air Act was trained at Wertz Field. Today Institute Industrial Park sits where Wertz Field was once located.

In addition to becoming one of the largest communities for blacks in the state, Institute is also home to several Native American burial mounds belonging to the Adena culture. The mounds, located near the back of WVSC campus, were excavated by the Smithsonian Institution in 1883 and revealed several skeletons in near-perfect condition. The mound remains in tact at the Shawnee Park in Institute, surrounded by a golf course and community pool. Today the Shawnee Park community center is a designated pick up point in case of an emergency evacuation.

Given the tendency for communities of color and low socio-economic status to suffer disproportionately from environmental burdens, it is no surprise that this cradle of African American culture in West Virginia was selected to house the production and 
mass storage of Methyl Isocyanate. Fortun (2001) proposes that Union Carbide selected Institute for reasons similar to choosing Bhopal, India for a site of MIC production - the semblance of a powerless and acquiescent population in need of modernity would make for little or no backlash to plant practices. Carbide's propensity toward racialized practices is further demonstrated by the working conditions at the Institute Plant. For many years Union Carbide maintained segregated working quarters and lavatories until the late 1960 s.

And they [African Americans] all had menial jobs, [a friend] told me they couldn't go into the same bathroom [as whites] until the late 60s. I couldn't believe it [...] blacks could not use the same bathroom whites used until the late 60s. This is ridiculous! (Sobey, Personal Interview, 2014)

African Americans were routinely refused managerial positions at the plant, despite having advanced degrees in chemistry, and were offered custodial jobs. Instead, whites from outside communities were given the more prestigious and better-paying jobs. Today tensions persist between the predominantly African American communities of Institute and Pinewood and the surrounding primarily white communities of Dunbar, St. Albans, and South Charleston. However, these acts of intentional racism are only the beginning of how race shapes this community. These tensions endure today in the battle to incorporate the township.

Efforts to preserve the culture and history of Institute are essential components of the struggle to maintain its classification as an unincorporated township. An unincorporated township has several key defining characteristics: first, this township lies outside the borders of an incorporated township; second, it shares at least one border with 
a municipality and serves as an area for unexpected growth and expansion; third, it is primarily residential; fourth, it is characterized as being low-income according to the US census (Anderson, 2008). Generally speaking there are two types of unincorporated townships: rural settlements that lack critical infrastructures (plumbing, sewage, etc.) and urban fringe areas that become home to the unwanted facilities (LULUs) of nearby city centers. Lastly, and most importantly for the context of this study, unincorporated townships are historically created in order to flee racial segregation and discrimination (Anderson, 2008). These communities have no local or municipal government and strictly rely on county-level governance. Unsurprisingly, this lack of oversight often results in neglect and lack of procedural justice in these urban (and sometimes rural) developments.

Because there is no municipal body of government, unincorporated townships often develop several differing committees in order to create democratic outlets and systems for decision-making within their boundaries. As discussed above in the history of People Concerned About MIC, the creation of People Concerned was followed by the formation of several other neighborhood groups. These groups include: the National Institute for Chemical Studies (NICS), the Kanawha Putnam Emergency Planning Committee, the Community Safety Assessment Group, and the Sub-Area Chemical Improvement Council. People Concerned was at odds with these different groups for two main reasons. First, these groups often received monies from the chemical plant and were far too "polite" in their dealings with plant representatives. Secondly, these groups supported the annexation of Institute into Dunbar. 
The annexation of Institute is controversial for several reasons. The absorption of Institute into Dunbar would theoretically prove to be financially beneficial for Institute citizens because it would create a formalized government that neighbors the Institute Plant. Hypothetically, that bureaucratic body could force the plant to pay taxes to nearby affected communities. There are of course, differing opinions on how fairly this money would be distributed between the "old" and "new" parts of Dunbar. However, in August 2012 the city of Nitro annexed a three-foot -wide strip of land surrounding BayerCrop Science and the Industrial Park into their city. As a result, BayerCrop Science and companies functioning within the Industrial Park are exempt from paying any municipal fees and taxes to nearby communities due to a municipal loophole ${ }^{6}$. Therefore, the initial monetary benefit for the annexation of Institute is no longer applicable.

According to informants, the most important reason for preventing the annexation of Institute into Dunbar is to preserve Institute's unique racial and cultural history. When asked why she was opposed to the annexation of Institute, one informant explains:

HISTORY. Institute is the only town in this valley with substantial history [...] those wanting to incorporate aren't doing it to better the community. They want to tell their neighbors how to use their property. (Sobey, Personal Interview, 2014) The subtle erasure of African American history, an incidental result of annexation, reflects Pulido's concern with unintentional racism. These inadvertent acts of racism encourage on-going tensions between Dunbar (a primarily white community) and Institute (primarily African-American) that make grand, intentional acts of racism possible today. In fact, several of my participants shared stories of discrimination and

\footnotetext{
${ }^{6}$ Rusty Marks, Following Nitro action, Carper wants annexation loophole closed, Charleston Gazette. July 24, 2012
} 
racial profiling suffered at the hands of white colleagues at the Department of Environmental Protection, neighbors, and even Dunbar police. These testimonies, juxtaposed with the history of Institute, demonstrate how race impacts and shapes the dynamics of Institute, WV.

\subsection{Discussion}

Using a subaltern environmental justice lens for examining the data produced in six oral histories, I am able to better understand the origins and dynamics of the grassroots group People Concerned About MIC, as well as how individuals understand MIC production in Institute, WV. Through four different frameworks of analysis (diagnostic, prognostic, motivational, and scalar), I have successfully identified core issues, strategies, and tactics for attracting new activists based on the perspective of the individual. The following section critically explores how my case study fits into broader conversations of NIMBY ism, militant particularism, and environmental racism. But first, I'd like to take the time to reflect on my data and methodology.

The organic shift of my methods fundamentally challenged my approach to this project, as well as my approach to, and understanding of, environmental justice. The shift from semi-structured interviews into oral histories has effectively de-centered the original source of knowledge production (myself) for this project, and forced me to reconcile with the important role of my informants as being sources and producers of knowledge equally. I learned that often, our conceptualization of a particular environmental struggle is framed through what is most accessible and relatable to ourselves: for me, this was the Bhopal disaster. But by praxis of situated knowledge, I was able to see that for those 
living next door to the Institute Plant, the Bhopal disaster was not where the struggle against MIC began.

I would like to critically reflect on three aspects of this project. First, I must address critiques of oral histories. It is probable that many of my informants misremembered events or activities that took place several years ago. Human error and nostalgia does lend itself to alter the actuality of events in such a way that reflects an individual's desires. This was particularly difficult for me to grapple with because I fell into the trap of treating the testimonies of my informants as absolute truth, rather than as an approach to knowledge seeking (as Andrews et al, 2006; Jackson and Russell, 2010; Portelli, 1981; Riley and Harvey, 2007 warn against). In part this is due to my role as an outsider conducting "insider" research. My position as a young, white, Texan made it difficult for me to feel comfortable making objective claims about my informants and their struggles. But I found that by bolstering the oral histories with archival work, I was better able to parse through the individual experiences of informants vs. historical events, and understand how they shaped one another. For example, much of the history of Institute provided during recording sessions with informants was confirmed and elaborated upon using the West Virginia state archives.

It is also important that I critically reflect on how my positionality may have significantly altered the data provided by my informants. An important part of using qualitative methodologies is the researcher's ability to not only recognize how their informants are implicated within systems, but how the researcher is positioned within them as well. It is the reality that many of the stories shared, including the ways in which they were delivered, was influenced by my position. In order to ensure that the product of 
my research accurately represented People Concerned and Institute, I maintained open lines of communication with several of my informants - sharing with them the difficulties I had understanding or interpreting certain data. It is because of the relationships I built with my informants, and our ability to openly discuss the direction of my project that I feel the story being told within this document is a fair and accurate portrayal of MIC production and grassroots activism in Institute, WV.

Lastly, I must reflect on the methodological shift itself and the implications it withholds for this project. The Bhopal disaster served as my point of entry for this research, as reflected by the organization of this paper. I am able to see now that my original plan to conduct semi-structured interviews, and the way I structured my interview guide was laden with subliminal assumptions about the experiences of my informants before I even met with them. Approaching my data using theories of embodied experience and situated knowledges forced me to view my informants as knowledge producers and relocated knowledge production to those occupying the margins, resulting in a much more enlightened approach to environmental justice scholarship.

\subsection{Environmental Injustice in Institute}

Framework analysis has revealed that MIC production in Institute, WV confirms environmental justice literature according to the four core components of the movement: distributive injustice, procedural injustice, environmental racism, and locational conflict. I should clarify however, that environmental justice literature is a tool for critically examining the reality and lived experiences of marginalized communities and that my case study (or any other) does not simply fulfill theories and ideas about what constitutes 
environmental injustice - this became clear to me through the use of oral histories. The fluidity of oral histories allowed informants to freely discuss the issues that mattered most to them, often these issues were historical or place-based in nature. It was through the perspectives of my informants that I uncovered that the location of conflicted needed to shift away from MIC at the plant and onto the racialized creation of Institute, WV.

As Bullard (1990) and countless others have determined, and as my informants echo, Institute suffers due to an imbalanced distribution of undesirable land use projects (MIC production and storage). My informants demonstrate a belief that Institute was selected for MIC production because of the racial composition of the community, lending itself to traditional interpretations of distributive injustice and environmental racismreaffirming Bullard's findings that environmental racism continues to be relevant for examining environmental justice. The results of my diagnostic framework analysis show that PCMIC activists remain primarily concerned with long-term exposures to chemical emissions, concluding that disputes within Institute have remained consistent since Bullard's work with the community in the late 1980s.

Despite the group's main rallying cry of aiming to enforce chemical safety throughout the valley, the group has extended its efforts informally by taking on the fight against the annexation of Institute. During the expansive lull of group activity, members of People Concerned took it upon themselves to successfully circulate a counter-petition that challenged the vote to annex Institute into Dunbar. The fight to preserve Institute's unincorporated status, having little to do with chemicals or chemical safety, demonstrates that People Concerned is more than just a chemical safety group. Rather, People Concerned believes that environmental justice is also defined and achieved by preserving 
a culture and history important to community members in Institute. This echoes Young's (1990) assertion that not all forms of justice are achieved in quantifiable measurements and complicates, perhaps, how procedural injustice is discussed and remediated. This extension of the group's practices represents the core tenet of subaltern environmentalism according to Pulido (1996): for subaltern communities, the ability to achieve environmental justice is inherently linked to achieving class, economic, gender, health, and environmental equality.

The unincorporated status of Institute, a clear demonstration of procedural injustice, has lead to the creation of several feuding community groups. These groups, comprised of varying class and ethnic backgrounds, have differing perspectives on how to best navigate politics surrounding the chemical plant. This has made it increasingly difficult to reach a consensus on any plan of action. I assert that these varying perspectives on annexation (and the chemical plant) reflect different racialized experiences, dependent on their positionality within several overarching structures.

As described by my informants, groups led by white individuals were more likely to accept compromise with the chemical plant and supported the annexation of Institute into Dunbar. Similarly, the shift from African American PCMIC group leaders to a young white woman leader has altered the strategies and framing techniques used. These recent changes in approaches reflect the strategies and tactics of mainstream environmentalism: lobbying and working within the established legal system to propose legislation, safety regulation and enforcement.

The shift away from more horizontally organized and grassroots-based strategies to more mainstream efforts is most clearly demonstrated by an inconsistency between the 
diagnostic and prognostic framework analyses. Despite identifying race as the primary factor that has led to the community's environmental burdens, race is not in the forefront of their solutions and strategies. The disjuncture between these two frameworks raises many questions concerning the "marketability" of using race and racism as a rallying cry. Racial equality is clearly important to PCMIC, as demonstrated when my informants shared the history of Institute with me, viewing it as a critical part of PCMIC's history and development. Likewise, stories of continued racial discrimination illustrate that race continues to shape the seemingly uphill battle PCMIC faces with the chemical industry and state and federal governments. However, PCMIC was never framed as a "black grassroots movement", despite individuals openly siting environmental racism as the core reason their community suffers. Rather, PCMIC chose to more broadly frame their grievances as pertaining to 'chemical safety' or 'quality of life'. This is best demonstrated with the inability for PCMIC to find a lawyer willing to represent their 2011 lawsuit as a Civil Rights cause.

It is likely that People Concerned and their demands were not taken seriously because of the racial, socio-economic, and unincorporated status of their community. As discussed above, Institute and its community members have been structurally disadvantaged since the creation of their township. Additionally, small grassroots movements already bear the burden of proof when disputing environmental degradation with large companies and must adhere to the language of those in power. This is evident in the rejection of PCMIC's health survey due to its so-called "lack of rigor". In order to attract the interests of white elites and outsider activists (which often have more influence 
on policy), PCMIC has been inadvertently forced to prioritize issues more accessible to those in positions of power.

Similarly, framing MIC in Institute through the Bhopal disaster overshadows the racial and long-term exposures of Institute community members. The grandeur of the Bhopal disaster provides PCMIC with a cause to rally behind that reaches the white elite communities in Charleston that would be affected if an MIC leak comparable to Bhopal occurred. However, the ability for governments and media to naturalize catastrophes such as the Bhopal disaster means that using industrial disasters as a framing device is harmful for movements addressing structural inequalities. In fact a brief media discourse analysis I conducted on the representation of the Bhopal disaster in the Charleston Gazette revealed that West Virginian journalists were far more concerned with protecting jobs at the Institute plant and easily explained away the Bhopal disaster by blaming the disaster on an inept workforce - this of course is laden with cultural and racial prejudices. The ephemeral and sensationalized nature of how society responds to industrial disaster essentially neglects the structural processes that lead to catastrophes and uneven sitingbased decisions.

However, People Concerned did eventually see some success in regard to identifying with the Bhopal disaster. In October 1986 the Community Right-to-Know $\mathrm{Act}^{7}$ was instituted at a national level and in March 2011 MIC was removed from the

\footnotetext{
7 The Community Right to know Act has two core components: first, communities and states are required to establish efficient and comprehensive emergency evacuation plans; second, communities and states are required to create programs dedicated to the collection and dissemination of all toxic materials and processes within surrounding communities. Effectively, the Community Right to Know Act forced any company working within the Institute plant to disclose any known harmful chemicals to community members (WVDHSEM, 2015).
} 
Institute plant (both storage and production). Although these actions help prevent "another Bhopal" from happening, they do not address the subliminal and non-intentional actions rooted in racism and classism which lead to the siting of noxious facilities in lowincome, minority communities.

Starting the story of People Concerned with the Bhopal disaster effectively erases the struggles that took place in Institute before MIC came to Institute, WV and the struggles that continue since MIC has left. Embedded within the conundrum of whether or not using Bhopal as a mechanism for activist efforts is beneficial, there lies two critical readings of place. The first is the role of militant particularism in "scaling up" the environmental justice movement. Today, there is much scholarship surrounding the creation of a transnational environmental justice movement that is dedicated to bridging the first and third worlds. These notions in many ways expand upon Bullard's call for a large-scale environmental justice movement achieved through a network of black grassroots activist groups.

Further, using the Bhopal disaster as a point of departure for MIC activism in Institute complicates the use of NIMBY terminology as it may be applied to People Concerned. Although informants expressed extreme gratitude and relief regarding MIC being removed from the Institute Plant, I later discovered that MIC was available for purchase in China through the Internet. This embodies one of the largest critiques of NIMBY movements: that they further displace an unwanted land use, often to new minority communities. Critiques of NIMBYism would undoubtedly put down PCMIC for this displacement. However, as stated above, it has been determined that People Concerned is not only a group about MIC; it is also a group dedicated to maintaining a 
cultural and historical community. Therefore, critical ideas about what defines a NIMBY movement are harmful for PCMIC because it reduces their struggle to MIC production and storage and the Institute Plant, thus erasing the historical and place-based struggle that has existed decades prior.

Further still, subaltern communities approach locational conflict much differently than elitist neighborhood groups that displace LULUs. Recall my previous discussion of subaltern vs. mainstream environmentalism. Mainstream environmental activists are not the population suffering first-hand from a given land use, rather it is the health and every day lived experience of the subaltern that is immediately impacted by said land use (Pulido 1990). Although both groups may displace environmental burdens, subaltern activists are driven by survival and an attempt to protect a minimal standard of living: clean air and water, economic prosperity, bodily health, and community health. To refer to PCMIC as a NIMBY movement, accompanied by the popular critiques of NIMBY, is to de-legitimize a fight for their lives.

Place has the power to thwart critiques of NIMBY movements by highlighting the everyday struggles of individuals. The in-depth exploration of a place allows for a more nuanced understanding of the resources available and structures in place that are conducive to a more "survivalist" approach to combatting LULUs. I found that oral histories were quite effective at revealing how perceptions of place inform lived experiences and vice-versa. Oral histories as a methodology leave much to be explored by geographers interested in the dialectic creation of place and activism. 


\subsection{Conclusion}

This study has provided an in-depth look at a small grassroots movement in Institute, WV using a subaltern environmental approach that seeks to shift the production of knowledge to the margins of my informants. Through an analysis of oral histories, I have successfully extended the work of Bullard (1990) and shifted discussions of environmental justice in Institute from a focus on MIC production to the historical and racialized creation of an unincorporated township. The testimonies of my informants reveal that race shapes the dynamics of People Concerned and emphasizes the continued importance of environmental racism as a lens through which locational conflicts can be accurately dissected, further complicating NIMBY literature as it is applied to grassroots movements of color. Likewise, this study emphasizes the role of place, as informed by race, in the materialization of environmental justice conflicts. Consequently, this project attempts to bridge gaps within oral history research by drawing on the importance of place and how it shapes the perspectives of individuals and in turn, affects the dynamics of grassroots movements.

Informed primarily by the perspectives and lived experiences of individual PCMIC activists, this study highlights the importance of embodied exposures and exemplifies the subaltern environmental justice framework. By shifting my analysis to the margins using oral histories, I conclude that using the Bhopal disaster as a point of entry for discussing conflict in Institute is limiting because it: first, it erases the long-term exposures that begun decades prior to MIC production; and secondly, neglects on-going struggles that exist within Institute due to the unincorporated status of the community. 
If I revisit Pulido $(1990,2000)$ and heed her warning not to fetishize the siting processes of a facility, as well as reflect on the value of subaltern environmentalism and oral histories as methodological approaches, I wonder how locational conflicts can be even further removed from the siting of a facility. Bullard (1990) and Pulido (1990) both purport that grassroots efforts begin with how individuals perceive conflict, based on personal experiences and ideologies - shaped by varying positionalities. I take this one step further and propose the body as a site of conflict: where the complex structural and decision-making processes that lead to facility siting collide with other forms of structural oppression (racism, sexism, classism, etc) and create conflict.

How can oral history be used to relocate the location of conflict, yet again, to the bodies impacted by LULUs? And how is the body implicated when we "scale up" activist efforts? In future research I aim to further investigate how the material body may serve as a site of conflict, moving conversations of locational conflict away from geographic coordinates and onto the corporeal form by drawing on the relationship between feminist theory and literatures. The linkage between feminist methodologies and oral histories is strong and I believe this project has set the groundwork for me to conduct future feminist-centered environmental justice research. Perhaps most importantly, I have learned to navigate the moral complications associated with doing outsider fieldwork and have been able to provide a useful project that benefits my informants. 


\subsection{Appendix}

Image 1. A woman holds her child while reading the Downwind News. (Downwind News, 1988)




Image 2. A photograph taken of a child's daycare center, located on West Virginia State College campus. Photograph taken on a "toxic tour": Sobey, 2014.

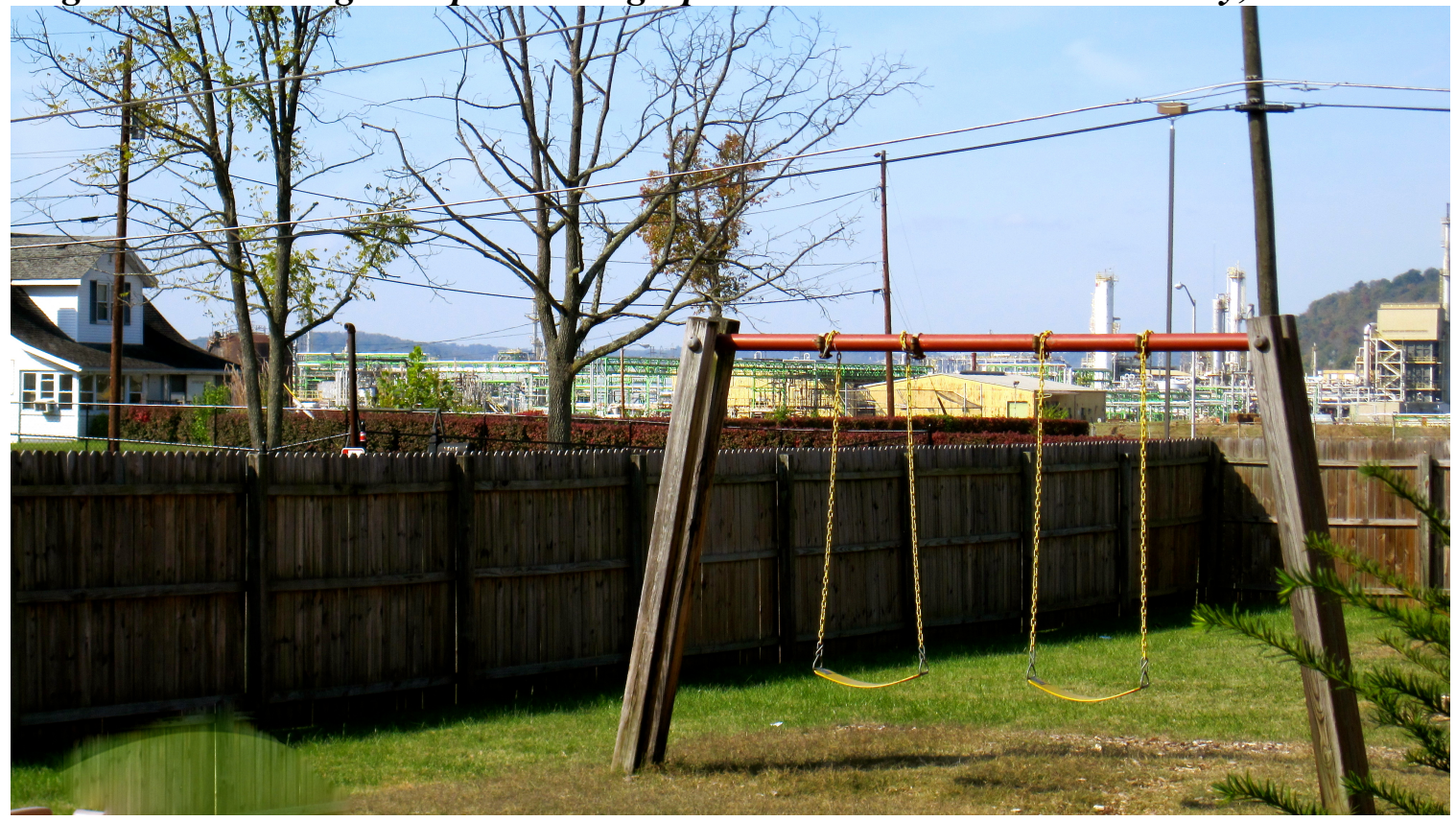


Image 3. A shelter-in-place placard located outside a campus building. Photograph taken on "toxic tour": Sobey, 2014.

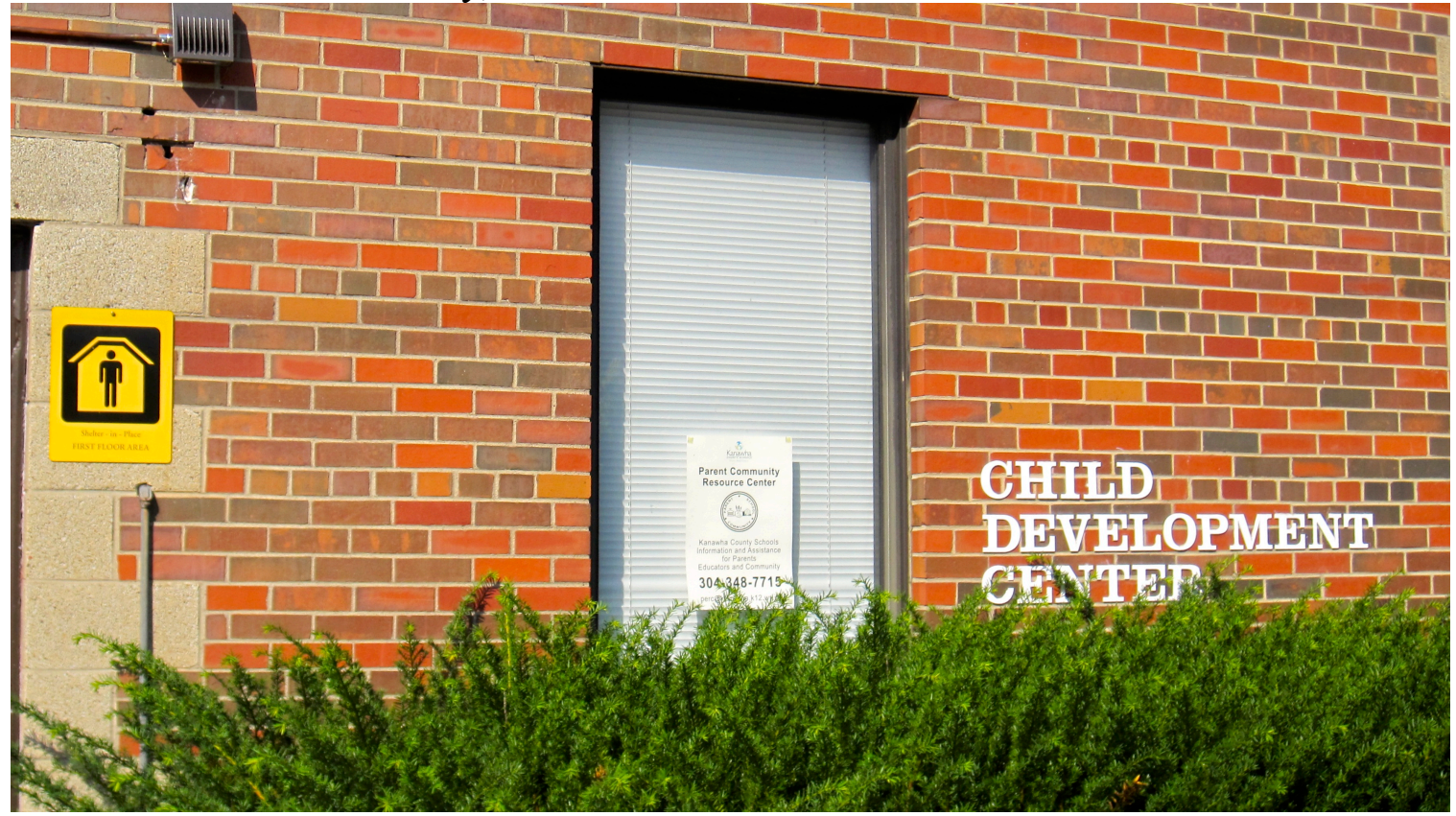




\section{Bibliography}

Anderson, M. (2008). Cities Inside Out: Race, Poverty, and Exclusion at the Urban Fringe. UCLA Law Review. 61 (5) 1095-1160

Andrews, G., Kearns, R., Kontos, P., Wilson, V. (2006). 'Their finest hour': older people, oral histories, and the historical geography of social life. Social \& Cultural Geography, 7(2) 154-177.

Bayer CropScience. (2008). Draft 1. Community Relations Strategy. Retrieved from http://media.wvgazette.com/static/cropsciencestrategy.pdf

Bell, S E. (2013). Our Roots Run Deep as IRONWEED: Appalachian women and the fight for Environmental Justice. University Illinois Press.

Buckingham, S and Kulcur, R. (2009). Gendered Geographies of Environmental Justice. Antipode 41 (4) $659-683$.

Bullard, R. D. (1990). Dumping in Dixie: race, class, and environmental quality. Boulder, Colorado: Westview Press.

Bullard, R. D. (1996). Environmental justice lives. The Brookings Review, 14(3), p. 48. Retrieved from http://www.jstor.org/stable/20080668

Bullard, R. D. (2002). Confronting environmental racism in the twenty-first century. Global Dialogue, 4(1), 34-48. Retrieved from http://search.proquest.com.www.libproxy.wvu.edu/docview/211519773?accounti $\underline{\mathrm{d}=2837}$

Castree, N. (2005). Nature. Abingdon, Oxon: Routledge.

Cutter, S. L. (2006). Hazards, vulnerability and environmental justice. Sterling, VA: London. 
Dembo, D., Idas, C. J., Kadwani, A., \& Morehouse, W. (Eds.). (1988). Nothing to lose but our lives: Empowerment to oppose industrial hazards in a transnational world. New York: New Horizons Press.

Edelman, M. (2001). Social Movements: Changing Paradigms and Forms of Politics. Annual Review of Anthropology. 30: 285- 317.

Egan, M. (2002). Subaltern Environmentalism in the United States: a historiographic review. Environment and History. 8(1) $21-41$.

Escobar, A (2008). Territories of Difference: place, movements, life, redes. Duke University Press.

Faber, D. (2008). Capitalizing on environmental injustice: The polluter-industrial complex in the age of globalization. Rowman \& Littlefield Publishers Inc.

Fisher, S. L., \& Smith, B. E. (Eds.). (2012). Transforming places: Lessons from Appalachia. Urbana: University of Illinois Press.

Fortun, K. (2001). Advocacy after Bhopal: Environmentalism, disaster, new global orders. Chicago: The University of Chicago Press.

Gaventa, J. (Ed.). (1980). Power and powerlessness : Quiescence and rebellion in an appalachian valley. Urbana: University of Illinois Press.

Gregg, N., \& Gamble, D. (2012). This land is your land. Transforming places: Lessons from appalachia (p. 47-62) University of Illinois Press.

Gregory, D; Johnston, R; Pratt, G; Watts, M; and Whatmore, S. (2009). $5^{\text {th }}$ edition. “Neighborhood" entry in The Dictionary of Human Geography (p. 103 -104). Blackwell Publishing. 
Guillette, E. (2008). The foul odor of capital: The union carbide disaster in Bhopal, India. Capitalizing on Catastrophe: Neoliberal strategies in disaster reconstruction (p. 173) Altamira Press.

Gunewardena, N., \& Schuller, M. (Eds.). (2008). Capitalizing on catastrophe: Neoliberal strategies in disaster reconstruction. United Kingdom: AltaMira Press.

Hay, Ian. (2010). $3^{\text {rd }}$ edition. Qualitative Methods in Human Geography. Victoria, Australia: Oxford University Press.

Haraway, D. (1988). Situated Knowledges: The Science Question in Feminism and the Privilege of Partial Perspective. Feminist Studies 14(3), 575 - 599.

Harvey, D. (1996). Militant particularism and global ambition. Justice, nature, and the geography of difference (p. 19-45) Blackwell Publishing.

Haught, J. A. (1971). Institute: It springs from epic love story. West Virginia History, 32(2), 101-107. Available at http://www.wvculture.org/history/journal_wvh/wvh32-2a.html

Holifield, R., Porter, M., \& Walker, G. (2009). Introduction spaces of environmental justice: Frameworks for critical engagement. Antipode, 41(4), 591-612. doi:10.1111/j.1467-8330.2009.00690.x

Hutchison, R. (2012). Stop the bombs. Transforming places: Lessons from appalachia (p. 19-31) University of Illinois Press.

Jackson, P. and Russel, P. (2010). Life History Interviewing. In DeLyser et al ( $1^{\text {st }}$ Ed) The SAGE Handbook of Qualitative Geography, p. 172-192. 
Keefer, L. E. (1994). On the homefront in World War II: Soldier-scholars at West Virginia State College. West Virginia History, 53, 119-132. Available at http://www.wvculture.org/history/journal_wvh/wvh53-7.html.

Kersey, L. (2014, January 20). Chemial-related Hospital Admissions Rise. Charleston Gazette. Retrieved from: http://www.wvgazette.com/News/201401180073

Kurtz, H. E. (2003). Scale frames and counter-scale frames: Constructing the problem of environmental injustice. Political Geography, 22(8), 887-916. doi:http://dx.doi.org/10.1016/j.polgeo.2003.09.001

Lake, R. W. (1993). Rethinking NIMBY. Journal of the American Planning Association, 59(1), 87. Retrieved from http://search.ebscohost.com/login.aspx?direct=true\&db=f5h\&AN=9608215013\&s $\underline{\text { ite }=\text { ehost-live }}$

Lake, R. W. (1996). Volunteers, NIMBYs, and environmental justice: Dilemmas of democratic practice. Antipode, 28(2), 160-174.

MacKian, Sara. (2010). The Art of Geographic Interpretation. In DeLyser et al ( $1^{\text {st }}$ Ed) The SAGE Handbook of Qualitative Geography, p. 359 - 372.

Martin, D. G. (2003). "Place-framing" as place-making: Constituting a neighborhood for organizing and activism. Annals of the Association of American Geographers, 93(3), 730-750. Retrieved from http://www.jstor.org/stable/1515505

Martinez-Alier, J., Anguelovski, I., Bond, P., Del Bene, D., Demaria, D., Gerber, J.F., Greyl, L., Yanez, I. (2014). Between activism and science: grassroots concepts for 
sustainability coined by Environmental Justice Organizations. Journal of Political Ecology 21 p. 19-60.

McNeil, B. (2011). Combatting Mountaintop Removal: New directions in the fight against big coal. University of Illinois Press.

Molenda, R. (2014, January 9). Thousands of Residents Warned to Not Use Water. Charleston Gazette. Retrieved from: http://www.wvgazette.com/News/201401090044.

Morgan, B. S., \& Cork, J. F. (1893). The West Virginia colored Institute. In History of Education in West Virginia (p. 189-194). Retrieved from http://www.wvculture.org/history/education/wvstatecollege01.html

(n.d.). A timeline of African-American history in West Virginia. Retrieved from http://www.wvculture.org/history/timeline.html

Nicholls, W. J. (2007). The geographies of social movements. Geography Compass, 1(3), 607-622.

People Concerned About MIC (1988). The Downwind News (community newsletter).

Pickering, M and Lewis, A (Directors). (1991). Chemical Valley (Documentary Film). United States: Appalshop.

Popper, F. J. (1985). Environment, 27(2), 6. Retrieved from http://search.ebscohost.com/login.aspx?direct $=$ true $\& d b=f 5 h \& A N=8500006579 \&$ s $\underline{\text { ite }=\text { ehost-live }}$

Portelli, A. (1981). The Peculiarities of Oral History. History Workshop, 12 p. 96-107. Portelli, A. (2011). They Say in Harlan County: An Oral History. New York: Oxford University Press. 
Pulido, L. (2000). Rethinking Environmental Racism: White Privilege and Urban Development in Southern California. Annals of the Association of American Geographers. 90 (1), 12-40.

Pulido, L. (1996). Environmentalism and economic justice :Two Chicano struggles in the southwest. Tucson: University of Arizona Press.

Renfrew, D. (2011). The Curse of Wealth: Political Ecologies of Latin American Neoliberalism. Geography Compass. 5(8) $581-594$.

Riley, M., Harvey, D. (2007). Talking geography: on oral history and the practice of geography. Social \& Cultural Geography, 8(3) 345-351.

Roche, M. (2005). Historical research and archival sources. In I. Hay (Ed.), Qualitative research methods in human geography: Second edition (p. 133)

Schlosberg, D. (2004). Reconceiving environmental justice: Global movements and political theories. Environmental Politics, 13(3), 517-540.

Schroeder, R., Martin, K. S., Wilson, B., \& Sen, D. (2008). Third world environmental justice. Society and Natural Resources, 21(7), 547-555.

Smith, N. (2008). $3^{\text {rd }}$ edition, Uneven Development: Nature, capital, and the production of space. Athens, Georgia: The University of Athens Press.

Snow, D., \& Benford, R. D. (1988). Ideology, frame resonance, and participant mobilization International Social Movement Research, 1, 197-217.

Staff. (2008, August, 28). Blast rocks Bayer plant; Injuries reported; Area roads closed; Residents told to shelter in place. Saturday Gazette Mail. Retrieved from: http://www.wvgazette.com/News/Bayerexplosion/200904270376. 
Stephen L. Fisher and Barbara Ellen Smith (Ed.). (2012). Transforming places: Lessons from appalachia (1st ed.) University of Illinois Press Urbana, Chicago, and Springfield.

Swyngedouw, E., \& Heynen, N. C. (2003). Urban political ecology, justice and the politics of scale. Antipode, 35(5), 898-918. doi:10.1111/j.14678330.2003.00364.x

Sze, J., \& Londont, J. K. (2008). Environmental justice at the crossroads. Sociology Compass, 2(4), 1331-1354.

Taylor, D. E. (2000). The rise of the environmental justice paradigm: Injustice framing and the social construction of environmental discourses. The American Behavioral Scientist, 43(4), 508-580. Retrieved from http://search.proquest.com/docview/214765066?accountid=2837

The National Research Council. (2012). The use and storage of methyl isocyanate (MIC) at bayer CropScience. Washington, DC: National Academic Press.

Walker, G., \& Bulkeley, H. (2006). Geographies of environmental justice. Geoforum, 37(5), 655-659. doi:http://dx.doi.org/10.1016/j.geoforum.2005.12.002

Wapner, P. (2002). Ecological displacement and transnational environmental justice. Global Dialogue, 4(1), 20-33.

Ward, Ken. (2011). Residents sue to delay start-up of Bayer's MIC unit. Charleston Gazette. http://www.wvgazette.com/News/201102081007

Ward, Ken. (2011). Bayer gives up fight to restart Institute MIC unit. Charleston Gazette. http://www.wvgazette.com/News/201103181523 
Ward, Ken (2011). CSB study details potential MIC leak impacts. Charleston Gazette. http://www.wvgazette.com/News/201102241389

West Virginia Division of Homeland Security and Emergency Management (2014). WV Code Chapter 15-5A Emergency Response and Community-Right-To-Know Act. http://www.dhsem.wv.gov/resources/Pages/Emergencyrighttoknowact.aspx

Winchester, H., Rolfe, M. (2010) Qualitative Research and Its Place in Human Geogaphy. In I. Hay ( $3^{\text {rd }}$ Ed) Qualitative research methods in human geography: (p. $3-24)$

Woomer, W. (2012). “Just Get it Done”: Synthetic rubber in Institute. Goldenseal, 38(1), 24-25. Retrieved from http://www.wvculture.org/goldenseal/spring12/rubber.html

Young, I M (1990). Justice and the Politics of Difference. Princeton, New Jersey: Princeton University Press. 